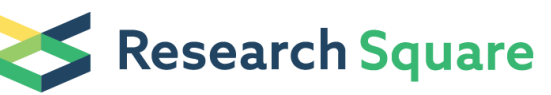 \\ Preprints are preliminary reports that have not undergone peer review. \\ They should not be considered conclusive, used to inform clinical practice, or referenced by the media as validated information.
}

\section{Association of Endocrine Disrupting Chemicals Levels in Serum, Environmental Risk Factors, and Hepatic Function Among 5- to 14-Year-Old Children}

\author{
Xiangjun Fu \\ Zunyi Medical University \\ Jie He \\ Zunyi Medical University \\ Deliang Zheng \\ Zunyi Medical University \\ Xuefeng Yang \\ Zunyi Medical University \\ Pan Wang \\ Zunyi Medical University \\ FangXu Tuo \\ Zunyi Medical University \\ Lin Wang \\ Zunyi Medical University \\ Shixu Li \\ Zunyi Medical University \\ Jie Xu \\ Zunyi Medical University \\ Jie Yu ( $0737717694 @ q q . c o m$ ) \\ Zunyi Medical University https://orcid.org/0000-0002-4796-7177
}

\section{Research}

Keywords: Nonylphenol, Bisphenol A, Phthalate, School-age children, Hepatic function.

Posted Date: June 2nd, 2021

DOI: https://doi.org/10.21203/rs.3.rs-531554/v1

License: (c) (i) This work is licensed under a Creative Commons Attribution 4.0 International License. Read Full License

Version of Record: A version of this preprint was published at Toxicology on October 1st, 2021. See the published version at https://doi.org/10.1016/j.tox.2021.153011. 


\section{Abstract}

Background: Endocrine-disrupting chemicals (EDCs) might increase the risk of childhood diseases by disrupting hormone-mediated processes that are critical for growth and development during childhood, however, the association among the exposure level of EDCs such as Nonylphenol (NP), Bisphenol A (BPA), Dimethyl phthalate (DMP) in children and environmental risk factors, as well as hepatic function has not been elaborated.

Objectives: This study aimed to discuss this interesting relationship among NP, BPA, DMP concentrations in serum, environmental risk factors, hepatic function of 5- to 14-year-old children in industrial zone, residential zone and suburb in northern district of Guizhou Province, China.

Methods: In Zunyi city, 1,006 children participated in cross-sectional health assessments from July to August 2018, and their parents completed identical questionnaires on the environmental risk factors of EDCs exposure to mothers and children. Serum NP, BPA and DMP concentrations were measured by high performance liquid chromatography (HPLC). Serum alanine aminotransferase (ALT), aspartate aminotransferase (AST), AST/ALT, total bilirubin (TBIL), direct bilirubin (DBIL) and indirect bilirubin (IBIL) were detected with automatic biochemical analyzer.

Results: The median concentrations of serum NP, BPA, and DMP in the participants were $45.85 \mathrm{ng} / \mathrm{mL}, 26.31 \mathrm{ng} / \mathrm{mL}$ and $31.62 \mathrm{ng} / \mathrm{mL}$, respectively, which were higher than the environmental concentration limits of the U.S. National Environmental Protection Agency (EPA). Hair gels used during pregnancy, types of domestic drinking water, nail polish and cosmetics used by children were significantly positive correlated with serum NP concentration $(P<0.05)$. Gender, feeding pattern, plastic water cup used during pregnancy, hair spray and perfume use for children, duration of children birth, materials for baby bottle or cup and ways to plastic products were significantly positively correlated with serum BPA concentration $(P<0.05)$. Gender, perms used during pregnancy, hair spray and perfume use for children, using plastic lunch box during pregnancy, duration of children birth, exposure to pesticides, parents' occupations were significantly positively correlated with serum DMP concentrations $(P<0.05)$. Serum NP $(\beta=0.296$, $P=0.036)$ and $\operatorname{DMP}(\beta=0.316, P=0.026)$ concentrations and TBIL level were significantly positively correlated. Serum NP concentration and the levels of IBIL $(\beta=0.382, P=0.006)$ are significantly positively correlated. Cosmetics used during pregnancy significantly increased AST level $(\beta=2.641, P=0.021 \rrbracket$. There was a positive correlation between the frequency of hair spray and perfume use for children and the AST ( $\beta=4.241, P=0.022)$.

Conclusion: NP, BPA and DMP, which were commonly detected in the serum of children aged 5-14 years old in Zunyi City, Northern Guizhou Province, China, were closely related to the environmental risk factors of exposure environment during pregnancy, infancy and school age. Exposure to NP, BPA and DMP would have negative effects on hepatic function, and these effects showed differences in gender and geographical location. Notably, The relationships were more evident in girls than in boys.

\section{Highlights}

1. Association between serum EDCs level and risk factors among 5-14 year old children.

2. Association in serum NP\BPAIDMP levels and hepatic function.

3. Serum EDCs level in school-age children was highest in industrial zone.

4. Differences in EDCs level and hepatic function in terms of sex and geographic area.

\section{Introduction}


The pollution of endocrine disrupting chemicals (EDCs), including Nonylphnol (NP), bisphenol A (BPA), phthalate (PAE), etc., has attracted more and more attention from the worldwide in recent years. EDCs, as exogenous compounds, can potentially interfere with the endocrine system, including hormone synthesis, release, transport and metabolism, during the development of the body (Bergman et al. 2015). EDCs can enter the human through skin contact, ingestion, respiration, placenta transfer and other ways (Gore et al. 2011), and be detected in human urine, blood, breast milk and adipose (Koch et al. 2012; Gore et al. 2015). The exposure levels of NP, BPA and PAE in human blood in different regions of the world were different, which were shown in Figure 1. Recent studies have shown that EDCs were closely related to human growth and development (Mao et al. 2012), diabetes (DM) (Predieri et al. 2020), metabolic disorders (Senthil et al. 2011), immune deficiency and cancer (Bansal et al. 2018; Kass et al. 2012). NP, BPA and PAE are typical representatives of EDCs due to their frequent usage in daily life (NIEHS. 2010). NP is an important fine chemical raw material and intermediate, mainly used in the production of surfactants, textile printing and dyeing auxiliaries, lubricating oil additives, pesticide emulsifiers and rubber stabilizers, etc. At present, the world's total production capacity was 500,000 tons/year, and China's current production capacity was 60,000 tons/year (Mao et al. 2012; Careghini et al. 2015). BPA, as an important monomer of polycarbonate and epoxy resin, is applied to the manufacture of various consumer goods, such as water cups, baby bottles, medical devices, etc. (Rezg et al. 2014). The output of BPA in China already reached 1.575 million tons/year in 2019, with increase of $9.38 \%$ from the previous year (Xiao et al. 2019). PAEs is a chemical mainly used as plasticizer to soften PVC (Larsson et al. 2014). China was currently the largest producer and consumer of phthalates in the world. Singh et al. 1972 reported that DMP exposure had maternal toxicity and effects on embryoifetal viability, growth and morphogenesis (Singh et al. 1972). However, few studies detected DMP concentrations in biomarker, hence, DMP, as a representative of the PAEs' metabolites, was chosen for detection in blood in this study. Therefore, the relationship between NP, BPA and PAEs exposure and health damage has become a research hotspot of environmental hygiene (Li et al. 2011).

In recent years, the economy of northern region of Guizhou in Western China was developing rapidly. The residents were suffering from the impact of environmental pollution, While enjoying the fruitful results of economic development, environmental problems were increasingly prominent with the further development of economy and the deepening of industrialization and urbanization. However, the general concern about the pollution of EDCs in northern Guizhou of china was not enough. 5-14-year-old school-age children were in a rapid period of growth and development, and the organ functions that have not been fully developed were more vulnerable to damage (Xie et al. 2015). Our previous studies showed that NP had adverse effects on reproduction, immunity and nervous system of rats (Jie et al. 2010a; Fan et al. 2010; Jie et al. 2013). Additionally, the serum NP level of Type 2 diabetes patients was higher than the levels in healthy controls (Luo et al. 2016). It was also reported that EDCs can affect the growth and development of fetus through placenta (Mose et al. 2007; Balakrishnan et al. 2010), and further lead to precocious puberty (Qiao et al. 2010), sexual development abnormality (Cai. 2013), obesity (Dai. 2014), psychological (Maserejian et al. 2014) and behavioral abnormality (Minatoya et al. 2018; Braun et al. 2014) in children through hypothalamus-pituitary-gonad axis (Fan and Yan. 2010). Intrauterine perinatal period and child growth and development period are two key periods of human growth and development. Research on reducing and preventing children diseases caused by EDCs exposure has gradually become one of the research focuses currently. Nowadays, research on the effects of EDCs on children's hepatic function is very scarce (Seth et al.1982 ). Therefore, this study aimed to take children aged 5-14-year as the subjects, for the first time to explore the association between the exposure level of serum NP, BPA and DMP in children and the main environmental risk factors, as well as the correlation between the exposure level of serum NP, BPA and DMP and the indicators of hepatic function.

Furthermore, this study was to try to provide epidemiological evidence for diseases caused by EDCs exposure and explore their pathogenic mechanism. 


\section{Materials And Methods}

\subsection{Study location}

The survey location was Zunyi City, which is the largest city in the north of Guizhou Province in Southwest China (Figure 2). This area was rich in coal resources and belongs to a typical acid rain area. The urban air pollution was characterized by "coal smoke, dust, industrial waste gas and motor vehicle exhaust composite" pollution. The pH value of atmospheric precipitation in this area was low, once as low as 3.2, which was a typical industrial city with serious environmental pollution (Yu et al. 2016). The city's jurisdiction included three districts: Huichuan District, Honghuagang District, and Bozhou District, which represented industrial zone, residential zone and suburb, respectively. The survey covered a total geographic area (105 square kilometers) with a total population of more than 6.24 million.

\subsection{Study design and subjects}

The study was a population-based, cross-sectional study, which conducted from July to August 2018 in Zunyi city, Guizhou Province. One thousand and six school-age children aged 5-14 who had summer physical examination in the People's Hospital of Honghuagang District, Zunyi City were randomly sampled, and questionnaire survey was carried out. Their parents or guardians completed identical questionnaires on the environmental risk factors of EDCs exposure to mothers and children. The blood samples were collected by the laboratory professionals of Honghuagang District People's Hospital and one part of them were used for serum tests by automatic biochemical analyzer, and the concentration of NP, BPA and DMP were measured by high performance liquid chromatography (HPLC) in serum separated from the other part of blood samples. The research scheme has been proved by the ethics committee of Zunyi Medical University (Certificate No.: 2015-1-017). A flowchart of exposure protocols and selection process of the participants was shown in Figure 3.

\subsection{Questionnaires and bloodserum collection}

The revised questionnaire on the environmental risk factors of EDCs exposure to mothers and children (Li. 2013) was used to list the environmental risk factors of EDCs exposed to kids aged 5-14 in Zunyi City. The questionnaire included: (1) basic information; (2) risk factors of exposure during pregnancy; (3) risk factors of exposure during infancy; (4) risk factors of exposure in children's current life. All detailed data was shown in Table 1. The data were collected in the form of an interview with parents or guardians, which was filled in by the uniformly trained investigators. Under the guidance of regulations, the related operations of this study and the research content of this study were explained in details to all research subjects and their personal privacy was kept strictly confidential.

$5 \mathrm{ml}$ of children's fasting peripheral venous blood was taken in the laboratory of the hospital, and then the serum was separated, numbered and stored in $\mathrm{a}-80^{\circ} \mathrm{C}$ refrigerator for HPLC.

\subsection{Serum analysis}

\subsubsection{Detection of serum concentrations of NP, BPA and DMP}

The serum concentrations of NP, BPA and DMP in the children were measured by HPLC. The lower limit of detection (LOD) for BPA concentration was $0.36 \mathrm{ng} / \mathrm{mL}$. The LOD level for both DMP and NP concentrations was $0.5 \mathrm{ng} / \mathrm{mL}$. Concentrations of EDCs below the LOD were assigned a value of 1/2 LOD. The peak time of NP, BPA and DMP standard samples was $3.7 \mathrm{~min}, 1.6 \mathrm{~min}$ and $3.6 \mathrm{~min}$, respectively. 


\subsubsection{Biochemical test of hepatic function}

Alanine aminotransferase (ALT), aspartate aminotransferase (AST), AST/ALT, total bilirubin (TBIL), direct bilirubin (DBIL) and indirect bilirubin (IBIL) in the children' serum were analyzed with automatic biochemical analyzer (model 7600; Hitachi, Ltd., Tokyo, Japan). 462 hepatic function test reports were collected.

\subsection{Statistical analysis}

JMP software (version 14, SAS Institute Inc, Cary, USA) was used to analyze and verify whether NP, DMP and BPA are related before all the data analysis. SPSS20.0 (Inc., Chicago, IL, USA) was used to process the data of this study. The enumeration data was described by the number of cases (composition ratio). Variance analysis was used for multiple groups comparison, and the level data of nonparametric statistics were analyzed by rank combination test. Differences in exposure levels by sex, age, and address were assessed. Multiple linear regression analysis was used to analyze the association among the levels of serum NP, BPA, DMP exposure, hepatic function and environmental risk factors. Binary logistic regression test was used to analyze the relationship between the level of serum NP, BPA, DMP exposure and hepatic function. The association between NP, BPA, DMP exposure concentration and the status of hepatic function outcomes in the children was estimated firstly, then an additional stratified analysis was conducted to explore the sex , age, and address differences. P-values $<0.05$ were considered to be significant. Coded and labeled categorical variables showed in Supplementary Table 1.

\section{Results}

\subsection{Profile of the participants}

A total of 1,006 questionnaires with serum information were collected. Among them, 544 participants were boys $(54.1 \%)$, and 462 were girls $(45.9 \%)$. The numbers of children from grade 1 to grade $3(45 \%)$ and from grade 4 to grade $6(33.9 \%)$ in primary school were top two, and the number of children aged 5-6 were the least (4\%), details was shown in Table 1.

Table 1. Sociodemographic characteristics of the participants. 


\begin{tabular}{|c|c|c|c|c|c|c|c|c|c|c|}
\hline \multirow[t]{2}{*}{ Characteristics } & \multirow{2}{*}{$\begin{array}{l}\text { Subjects } \\
\text { Number } \\
\text { (Percentage) }\end{array}$} & \multicolumn{3}{|l|}{$\mathrm{NP}$} & \multicolumn{3}{|l|}{ DMP } & \multicolumn{3}{|l|}{ BPA } \\
\hline & & $25^{\text {th }}$ & $50^{\text {th }}$ & $75^{\text {th }}$ & $25^{\text {th }}$ & $50^{\text {th }}$ & $75^{\text {th }}$ & $25^{\text {th }}$ & $50^{\text {th }}$ & $75^{\text {th }}$ \\
\hline \multicolumn{11}{|l|}{ Gender } \\
\hline Male & $544(54.1)$ & 42.88 & 45.42 & 48.92 & 26.02 & 28.13 & 33.98 & 23.44 & 27.57 & 33.60 \\
\hline Female & $462(45.9)$ & 42.69 & 45.13 & 48.79 & 25.86 & 28.76 & 36.73 & 24.05 & 27.44 & 33.81 \\
\hline \multicolumn{11}{|l|}{ Grade } \\
\hline Preschool & $25(2.5)$ & 41.00 & 43.15 & 48.38 & 27.29 & 28.91 & 47.44 & 23.64 & 25.79 & 34.61 \\
\hline Grade 1-3 & $453(45.0)$ & 42.71 & 45.20 & 48.55 & 25.81 & 28.63 & 36.04 & 23.47 & 27.41 & 32.91 \\
\hline Grade 4-6 & $341(33.9)$ & 42.91 & 45.20 & 48.99 & 25.72 & 28.14 & 33.46 & 23.31 & 26.35 & 32.87 \\
\hline $\begin{array}{l}\text { Grade one of } \\
\text { junior high } \\
\text { school }\end{array}$ & 187(18.6) & 42.50 & 45.28 & 48.87 & 26.23 & 28.47 & 35.46 & 24.64 & 29.30 & 36.82 \\
\hline \multicolumn{11}{|l|}{ Age } \\
\hline $5-6$ years old & $40(4.0)$ & 42.37 & 45.90 & 55.58 & 26.42 & 29.63 & 40.44 & 21.90 & 25.79 & 35.13 \\
\hline 7-8 years old & $334(33.2)$ & 42.67 & 45.07 & 47.90 & 25.44 & 27.90 & 35.98 & 23.56 & 26.68 & 31.99 \\
\hline $9-10$ years old & $261(25.9)$ & 43.76 & 45.67 & 50.16 & 25.97 & 28.63 & 34.17 & 23.47 & 27.12 & 32.91 \\
\hline $\begin{array}{l}11-12 \text { years } \\
\text { old }\end{array}$ & $218(21.7)$ & 42.75 & 45.20 & 48.79 & 25.83 & 28.25 & 33.46 & 24.07 & 27.17 & 33.99 \\
\hline $\begin{array}{l}13-14 \text { years } \\
\text { old }\end{array}$ & $153(15.2)$ & 42.48 & 45.21 & 48.48 & 26.23 & 28.24 & 35.34 & 24.67 & 28.72 & 37.08 \\
\hline \multicolumn{11}{|l|}{$\begin{array}{l}\text { Address for } \\
\text { children }\end{array}$} \\
\hline $\begin{array}{l}\text { Huichuan } \\
\text { District } \\
\text { (industrial } \\
\text { zone) }\end{array}$ & $282(28.0)$ & 45.09 & 50.29 & 53.15 & 26.36 & 30.60 & 48.28 & 24.65 & 29.91 & 44.65 \\
\hline $\begin{array}{l}\text { Honghuagang } \\
\text { District } \\
\text { (residential } \\
\text { zone) }\end{array}$ & $414(41.2)$ & 42.52 & 44.71 & 46.98 & 25.75 & 28.19 & 33.98 & 24.45 & 28.54 & 33.53 \\
\hline $\begin{array}{l}\text { Bozhou } \\
\text { District } \\
\text { (suburb) }\end{array}$ & $310(30.8)$ & 42.04 & 43.87 & 45.93 & 25.72 & 27.90 & 30.29 & 22.19 & 25.96 & 28.74 \\
\hline \multicolumn{11}{|l|}{$\begin{array}{l}\text { Decoration } \\
\text { times }\end{array}$} \\
\hline Undecorated & $611(60.7)$ & 42.50 & 45.20 & 48.89 & 25.97 & 28.23 & 35.19 & 23.44 & 27.12 & 32.91 \\
\hline $\begin{array}{l}\text { Decoration 1-3 } \\
\text { times }\end{array}$ & $395(39.3)$ & 43.00 & 45.28 & 48.55 & 25.84 & 28.47 & 35.22 & 24.07 & 28.64 & 35.04 \\
\hline
\end{tabular}




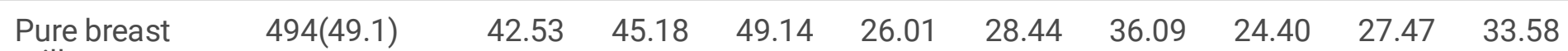
milk

$\begin{array}{llllllllll}\text { Mainly breast } \quad 260(25.8) & 42.43 & 44.75 & 48.38 & 26.06 & 28.21 & 34.17 & 23.82 & 28.05 & 33.99\end{array}$

milk,

supplemented

by milk

powder

Milk powder

feeding is the

$113(11.2)$

43.87

main method,

supplemented

by breast-

feeding

$\begin{array}{lllllllllll}\text { Milk feeding } & 139(13.8) & 43.75 & 45.67 & 49.13 & 25.72 & 27.30 & 32.06 & 23.64 & 27.92 & 35.90\end{array}$

\section{Frequency of \\ perms used \\ during \\ pregnancy}

\begin{tabular}{lllllllllll}
0 & $973(96.7)$ & 42.71 & 45.20 & 48.79 & 25.92 & 28.22 & 34.83 & 23.67 & 27.57 & 33.99 \\
\hline $1-2$ times & $33(3.3)$ & 45.11 & 47.12 & 50.39 & 26.92 & 34.17 & 55.73 & 22.47 & 24.44 & 29.50
\end{tabular}

\section{Frequency of \\ hair gels used \\ during \\ pregnancy}

\begin{tabular}{|lllllllllll|}
\hline 0 & $930(92.4)$ & 42.67 & 45.20 & 48.75 & 25.92 & 28.27 & 35.15 & 23.67 & 27.47 & 33.60 \\
\hline Several times & $76(7.6)$ & 43.35 & 45.88 & 49.73 & 26.11 & 28.72 & 35.50 & 22.81 & 27.89 & 34.08 \\
\hline
\end{tabular}

\section{Frequency of \\ cosmetics \\ used during \\ pregnancy}

\begin{tabular}{|lllllllllll}
0 & $894(88.9)$ & 42.69 & 45.18 & 48.79 & 25.86 & 28.44 & 35.22 & 23.67 & 27.47 & 33.68 \\
\hline $1-2$ times & $111(11.1)$ & 42.99 & 46.04 & 49.04 & 26.02 & 27.09 & 35.00 & 23.12 & 27.89 & 33.94
\end{tabular}

\section{Frequency of \\ using plastic \\ lunch box \\ during \\ pregnancy}

\begin{tabular}{|c|c|c|c|c|c|c|c|c|c|c|}
\hline $\begin{array}{l}1 \text { to } 3 \text { times } \\
\text { each day }\end{array}$ & $11(1.1)$ & 42.14 & 43.62 & 44.58 & 27.62 & 28.63 & 34.78 & 21.77 & 28.23 & 39.28 \\
\hline $\begin{array}{l}3 \text { to } 10 \text { times a } \\
\text { month }\end{array}$ & $16(1.6)$ & 43.79 & 45.92 & 52.86 & 26.57 & 26.92 & 33.68 & 23.41 & 26.77 & 34.08 \\
\hline $\begin{array}{l}3 \text { to } 10 \text { times a } \\
\text { year }\end{array}$ & $451(44.8)$ & 42.88 & 45.31 & 48.72 & 25.74 & 28.33 & 36.05 & 23.62 & 27.57 & 33.55 \\
\hline Never & $528(52.5)$ & 42.69 & 45.21 & $\begin{array}{l}49.14 \\
\text { Page } 7 / 3\end{array}$ & 26.23 & 28.27 & 34.15 & 23.70 & 27.47 & 33.73 \\
\hline
\end{tabular}




\section{Frequency of plastic water \\ cup used \\ during \\ pregnancy}

\begin{tabular}{|c|c|c|c|c|c|c|c|c|c|c|}
\hline Daily & $7(0.7)$ & 41.20 & 43.83 & 47.72 & 26.36 & 27.65 & 70.51 & 28.85 & 29.57 & 42.57 \\
\hline Often & $525(52.2)$ & 42.95 & 45.69 & 49.14 & 25.92 & 28.16 & 35.44 & 23.67 & 27.47 & 33.60 \\
\hline Occasionally & 182(18.1) & 42.43 & 45.21 & 47.27 & 26.03 & 29.08 & 34.38 & 22.36 & 28.30 & 33.99 \\
\hline Never & 292(29.0) & 42.50 & 44.85 & 48.38 & 25.81 & 28.59 & 34.73 & 23.60 & 27.10 & 33.27 \\
\hline \multicolumn{11}{|l|}{$\begin{array}{l}\text { Types of } \\
\text { domestic } \\
\text { drinking water }\end{array}$} \\
\hline $\begin{array}{l}\text { Commercial } \\
\text { bucketed } \\
\text { water }\end{array}$ & $865(86.0)$ & 42.69 & 45.18 & 48.72 & 25.83 & 28.23 & 35.32 & 23.67 & 27.47 & 33.99 \\
\hline Well water & $20(2.0)$ & 43.62 & 45.51 & 47.10 & 26.64 & 28.03 & 34.78 & 24.44 & 29.39 & 30.78 \\
\hline $\begin{array}{l}\text { Boiled tap } \\
\text { water }\end{array}$ & $49(4.9)$ & 42.52 & 46.58 & 50.81 & 26.19 & 28.54 & 33.17 & 23.48 & 27.27 & 31.85 \\
\hline $\begin{array}{l}\text { Commercial } \\
\text { bottled water }\end{array}$ & $9(0.9)$ & 41.23 & 44.83 & 46.57 & 25.71 & 26.58 & 90.37 & 25.29 & 33.55 & 51.00 \\
\hline $\begin{array}{l}\text { Mountain } \\
\text { spring water }\end{array}$ & $30(3.0)$ & 44.84 & 46.20 & 49.45 & 26.74 & 31.08 & 36.39 & 25.96 & 29.81 & 36.82 \\
\hline Other & $33(3.3)$ & 43.46 & 45.50 & 51.65 & 27.31 & 28.13 & 33.87 & 21.42 & 26.23 & 30.75 \\
\hline
\end{tabular}

\section{Frequency of}

pacifiers used

\begin{tabular}{|c|c|c|c|c|c|c|c|c|c|c|}
\hline $\begin{array}{l}\text { Occasional } \\
\text { used }\end{array}$ & $218(21.7)$ & 42.95 & 45.55 & 48.38 & 25.77 & 27.78 & 33.73 & 23.56 & 30.01 & 36.42 \\
\hline Often used & $67(6.7)$ & 42.61 & 45.88 & 49.73 & 26.05 & 31.76 & 37.40 & 26.35 & 32.13 & 45.75 \\
\hline Never used & 721(71.7) & 42.70 & 45.18 & 48.90 & 25.97 & 28.47 & 35.15 & 23.47 & 26.99 & 32.69 \\
\hline \multicolumn{11}{|l|}{$\begin{array}{l}\text { Numbers of } \\
\text { plastic toys }\end{array}$} \\
\hline None & $41(1.1)$ & 42.33 & 43.96 & 46.90 & 25.74 & 27.69 & 36.41 & 23.17 & 28.92 & 38.27 \\
\hline$\leq 10$ pieces & 135(13.4) & 43.01 & 45.71 & 49.63 & 25.67 & 29.61 & 35.34 & 22.49 & 26.70 & 29.57 \\
\hline$\leq 50$ pieces & $300(29.8)$ & 42.88 & 45.36 & 48.89 & 25.97 & 28.63 & 36.12 & 23.82 & 26.93 & 31.34 \\
\hline$\leq 100$ pieces & $321(31.9)$ & 42.67 & 45.21 & 48.79 & 25.86 & 27.80 & 34.17 & 23.61 & 27.81 & 33.53 \\
\hline ه100 pieces & 209(20.8) & 42.74 & 45.81 & 49.15 & 26.02 & 28.52 & 34.60 & 24.07 & 30.26 & 40.45 \\
\hline \multicolumn{11}{|l|}{$\begin{array}{l}\text { Materials for } \\
\text { food storage }\end{array}$} \\
\hline No microwave & 638(63.4) & 42.48 & 44.75 & 47.67 & 25.68 & 27.96 & 33.02 & 23.79 & 27.93 & 35.89 \\
\hline
\end{tabular}




\begin{tabular}{|c|c|c|c|c|c|c|c|c|c|c|}
\hline Chinaware & $317(31.5)$ & 42.32 & 44.65 & 48.31 & 25.79 & 27.96 & 32.38 & 24.51 & 28.12 & 34.84 \\
\hline $\begin{array}{l}\text { Heat-resistant } \\
\text { plastics }\end{array}$ & 19(1.9) & 43.35 & 46.66 & 49.93 & 25.57 & 26.82 & 29.08 & 26.70 & 31.33 & 47.07 \\
\hline $\begin{array}{l}\text { Heat-resistant } \\
\text { plastic wrap }\end{array}$ & $13(1.3)$ & 43.85 & 46.34 & 50.77 & 25.55 & 26.91 & 32.26 & 23.42 & 29.50 & 39.17 \\
\hline Aluminum foil & 19(1.9) & 42.70 & 44.13 & 46.70 & 25.24 & 26.74 & 33.07 & 25.55 & 30.09 & 34.55 \\
\hline \multicolumn{11}{|l|}{$\begin{array}{l}\text { Frequency of } \\
\text { hair dyes used } \\
\text { by children }\end{array}$} \\
\hline Never & $980(97.4)$ & 42.75 & 45.26 & 48.91 & 25.92 & 28.33 & 35.34 & 23.61 & 27.47 & 33.73 \\
\hline 1-2 times & $26(2.6)$ & 41.83 & 44.36 & 47.05 & 25.97 & 27.96 & 33.22 & 24.56 & 28.30 & 35.20 \\
\hline \multicolumn{11}{|l|}{$\begin{array}{l}\text { Frequency of } \\
\text { hair spray and } \\
\text { perfume use } \\
\text { for children }\end{array}$} \\
\hline Never & 737(73.3) & 42.70 & 45.18 & 48.53 & 25.93 & 28.30 & 35.34 & 23.71 & 27.89 & 33.99 \\
\hline 1-2 times & 267(26.7) & 42.87 & 45.31 & 49.32 & 25.92 & 28.22 & 35.00 & 23.31 & 26.66 & 33.21 \\
\hline \multicolumn{11}{|l|}{$\begin{array}{l}\text { Frequency of } \\
\text { nail polish and } \\
\text { cosmetics } \\
\text { used by } \\
\text { children }\end{array}$} \\
\hline Never & 703(69.9) & 42.51 & 45.06 & 48.75 & 25.93 & 28.22 & 35.76 & 24.11 & 28.22 & 35.18 \\
\hline 1-2 times & $301(30.1)$ & 42.99 & 45.52 & 48.82 & 25.92 & 28.50 & 33.67 & 22.81 & 26.28 & 31.51 \\
\hline \multicolumn{11}{|l|}{$\begin{array}{l}\text { Frequency of } \\
\text { plastic } \\
\text { tableware } \\
\text { used by } \\
\text { children }\end{array}$} \\
\hline Never & $356(35.4)$ & 42.43 & 44.73 & 49.45 & 26.20 & 28.35 & 35.34 & 22.95 & 27.35 & 33.53 \\
\hline $\begin{array}{l}1-3 \text { times in a } \\
\text { period of } 1-3 \\
\text { months }\end{array}$ & $592(58.8)$ & 42.99 & 45.51 & 48.89 & 25.84 & 28.13 & 34.71 & 24.16 & 27.47 & 33.73 \\
\hline $\begin{array}{l}\geq 10 \text { times in } \\
\text { one month }\end{array}$ & $58(5.8)$ & 42.70 & 45.46 & 48.25 & 26.92 & 30.34 & 37.56 & 26.06 & 30.54 & 43.04 \\
\hline \multicolumn{11}{|l|}{$\begin{array}{l}\text { Frequency of } \\
\text { fish and } \\
\text { shellfish } \\
\text { intake in } \\
\text { children }\end{array}$} \\
\hline Daily & $10(1.0)$ & 43.18 & 47.05 & 48.07 & 25.57 & 25.81 & 34.75 & 22.60 & 24.95 & 40.73 \\
\hline $\begin{array}{l}\text { Once to three } \\
\text { times a week }\end{array}$ & $294(29.2)$ & 42.98 & 45.42 & 48.39 & 25.69 & 27.29 & 32.98 & 24.64 & 28.45 & 39.06 \\
\hline Occasionally & $626(62.2)$ & 42.48 & 45.18 & 49.08 & 26.14 & 28.60 & 35.34 & 23.50 & 27.41 & 31.32 \\
\hline
\end{tabular}




$\begin{array}{lllllllllll}\text { Never } & 76(7.6) & 43.37 & 45.90 & 48.83 & 25.97 & 28.54 & 42.25 & 23.44 & 26.50 & 34.48\end{array}$

\section{Update \\ frequency of \\ plastic toys}

$\begin{array}{lllllllllll}\text { Weekly } & 119(11.8) & 44.09 & 47.25 & 50.31 & 26.87 & 29.08 & 34.50 & 25.50 & 31.34 & 40.50 \\ \text { Monthly } & 90(8.9) & 42.30 & 44.74 & 49.04 & 25.94 & 30.93 & 40.79 & 23.14 & 29.36 & 40.31 \\ \text { Half a year } & 343(34.1) & 42.82 & 45.18 & 47.27 & 25.77 & 28.21 & 37.09 & 23.62 & 28.35 & 34.03 \\ \text { Each year } & 430(42.7) & 42.73 & 45.21 & 49.14 & 25.83 & 28.05 & 33.45 & 23.67 & 26.53 & 30.13 \\ \text { Never } & 24(2.4) & 42.33 & 45.15 & 47.10 & 26.49 & 28.13 & 35.34 & 22.01 & 27.85 & 38.27\end{array}$

\section{Duration of} children birth

\begin{tabular}{lllllllllll}
$\begin{array}{l}\text { Premature } \\
\text { infant }\end{array}$ & $80(8.0)$ & 43.00 & 46.00 & 49.01 & 26.26 & 27.96 & 35.48 & 21.55 & 25.08 & 29.66 \\
$\begin{array}{l}\text { Late delivery } \\
\text { infant }\end{array}$ & $32(3.2)$ & 42.30 & 44.36 & 48.58 & 25.83 & 27.44 & 30.62 & 25.29 & 29.91 & 32.61 \\
\hline Full-term & $894(88.9)$ & 42.70 & 45.20 & 48.75 & 25.92 & 28.44 & 35.34 & 23.82 & 27.63 & 35.14
\end{tabular}

\section{Materials for baby bottle or}

cup

\begin{tabular}{lllllllllll} 
Glass & $529(52.6)$ & 42.48 & 45.21 & 48.89 & 25.92 & 28.44 & 35.10 & 23.62 & 27.28 & 33.60 \\
\hline Silica gel & $70(7.0)$ & 43.74 & 45.91 & 50.39 & 25.96 & 27.35 & 30.78 & 24.35 & 28.54 & 32.72 \\
\hline Plastic & $252(25.0)$ & 43.09 & 45.36 & 47.77 & 25.72 & 28.02 & 34.78 & 24.17 & 27.57 & 32.13 \\
\hline Stainless steel & $147(14.6)$ & 42.73 & 45.65 & 49.63 & 26.25 & 28.91 & 37.12 & 22.07 & 27.63 & 36.59 \\
Other & $8(0.8)$ & 42.18 & 42.51 & 45.42 & 29.46 & 40.00 & 48.56 & 32.91 & 42.94 & 76.69
\end{tabular}

\section{Whether \\ exposed to \\ pesticides}

\begin{tabular}{lllllllllll} 
Yes & $38(3.8)$ & 43.38 & 46.01 & 47.73 & 25.41 & 27.80 & 31.40 & 21.99 & 25.96 & 35.20 \\
\hline No & $968(96.2)$ & 42.70 & 45.24 & 48.89 & 25.93 & 28.33 & 35.34 & 23.69 & 27.57 & 33.60 \\
\hline
\end{tabular}

\section{Parent}

occupation

classification

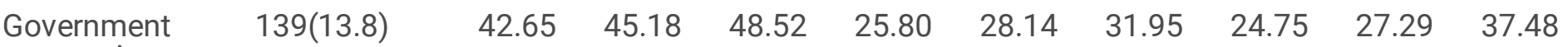
companies

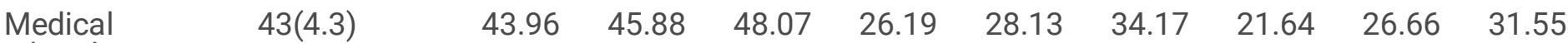

related

occupation 


\begin{tabular}{|c|c|c|c|c|c|c|c|c|c|c|}
\hline $\begin{array}{l}\text { Free small } \\
\text { business } \\
\text { (catering, } \\
\text { service, etc.) }\end{array}$ & $307(30.5)$ & 42.73 & 45.52 & 49.63 & 25.84 & 28.04 & 35.34 & 24.16 & 28.19 & 33.66 \\
\hline $\begin{array}{l}\text { Migrant } \\
\text { Workers }\end{array}$ & $45(4.5)$ & 43.74 & 45.71 & 49.45 & 25.59 & 27.78 & 33.99 & 22.51 & 25.12 & 29.22 \\
\hline Farming & $72(7.2)$ & 42.01 & 43.76 & 46.80 & 26.11 & 30.62 & 42.30 & 22.40 & 26.06 & 29.27 \\
\hline $\begin{array}{l}\text { Education } \\
\text { related }\end{array}$ & $43(4.3)$ & 43.62 & 45.89 & 48.41 & 27.66 & 32.30 & 36.13 & 25.96 & 29.39 & 33.53 \\
\hline Others & $357(35.5)$ & 42.75 & 45.04 & 48.75 & 25.97 & 28.76 & 35.34 & 23.68 & 27.47 & 34.62 \\
\hline \multicolumn{11}{|l|}{$\begin{array}{l}\text { Ways to } \\
\text { plastic } \\
\text { products }\end{array}$} \\
\hline $\begin{array}{l}\text { Drinking } \\
\text { utensils, cups }\end{array}$ & 161(16.0) & 42.71 & 45.42 & 48.25 & 25.81 & 28.10 & 32.18 & 23.01 & 27.27 & 32.13 \\
\hline $\begin{array}{l}\text { Containers for } \\
\text { meals, snacks, } \\
\text { fruits, etc. }\end{array}$ & 83(8.3) & 43.76 & 45.91 & 49.37 & 26.25 & 28.54 & 43.24 & 24.11 & 26.65 & 31.80 \\
\hline $\begin{array}{l}\text { Plastic toys } \\
\text { (LEGO etc.) }\end{array}$ & $254(25.2)$ & 42.32 & 44.74 & 47.72 & 25.39 & 27.36 & 34.78 & 24.16 & 28.30 & 33.35 \\
\hline $\begin{array}{l}\text { Small } \\
\text { household } \\
\text { items } \\
\text { (toothbrushes, } \\
\text { plastic bags, } \\
\text { plastic wrap, } \\
\text { etc.) }\end{array}$ & $355(35.3)$ & 42.88 & 45.24 & 49.14 & 26.42 & 28.72 & 36.53 & 23.62 & 27.80 & 36.59 \\
\hline $\begin{array}{l}\text { School } \\
\text { supplies }\end{array}$ & $129(12.8)$ & 43.42 & 46.05 & 49.30 & 25.72 & 28.23 & 33.98 & 22.68 & 25.96 & 31.28 \\
\hline Others & $24(2.4)$ & 43.02 & 45.20 & 48.07 & 26.49 & 28.13 & 34.17 & 25.10 & 30.28 & 42.41 \\
\hline
\end{tabular}

\subsection{Standard curve and concentration of NP, BPA and DMP}

The NP, BPA and DMP standard solutions were calibrated by HPLC, and the results of linear regression equation were calculated (Supplementary Table 2). The correlation coefficient of these linear regression equations were $\geq 0.999$. NP concentration was around $40.72-77.03 \mathrm{ng} / \mathrm{ml}$, with an average of $45.85 \mathrm{ng} / \mathrm{ml}$; BPA concentration was about $14.15-216.12 \mathrm{ng} / \mathrm{ml}$, with an average of $26.31 \mathrm{ng} / \mathrm{ml}$; and DMP concentration was around 22.51-132.07 ng/ml, with an average of $31.62 \mathrm{ng} / \mathrm{ml}$.

\subsection{Comparison of the concentrations of NP, BPA and DMP in serum by address, gender and age}

There was significant difference in the serum concentrations of NP, BPA, DMP in school-age children in Huichuan District (industrial zone), Honghuagang District (residential zone) and Bozhou district (suburb) $\left(F_{\mathrm{NP}}=548.961, P_{\mathrm{NP}}<\right.$ $\left.0.001 \rrbracket F_{\mathrm{BPA}}=189.198 \rrbracket P_{\mathrm{BPA}}<0.001, F_{\mathrm{DMP}}=112.476, P_{\mathrm{DMP}}<0.001\right)$. The serum concentrations of NP $(P<0.001), \mathrm{BPA}$ $(P<0.001)$, DMP $(P<0.001)$ in school-age children in industrial zone were higher than those in residential zone and 
suburb. The average concentration of NP in boys was $45.97 \pm 4.50 \mu \mathrm{g} / \mathrm{ml}$, and in girls was $45.71 \pm 4.42 \mu \mathrm{g} / \mathrm{ml}$; the average concentration of BPA in boys was $31.29 \pm 11.08 \mu \mathrm{g} / \mathrm{ml}$, and in girls was $28.00 \pm 11.87 \mu \mathrm{g} / \mathrm{ml}$; the average concentration of DMP in boys was $31.91 \pm 12.53 \mu \mathrm{g} / \mathrm{ml}$, and in girls was $33.28 \pm 15.61 \mu \mathrm{g} / \mathrm{ml}$. There was no significant gender difference in the concentration between boys and girls (Figure 4 and Supplementary Table 2). The results analysis showed in Supplementary Figure 2.

\subsection{Correlation between serum EDCs (NP, BPA and DMP) concentrations and environmental risk factors}

NP, BPA, and DMP concentrations in serum were used as dependent variables, and the environmental risk factors on the questionnaire were used as independent variables. The environmental risk factors that affected NP, BPA, and DMP concentrations in serum were analyzed by multiple linear regression.

The regression coefficients of hair gels used during pregnancy $(P=0.012)$, types of domestic drinking water $(P<$ $0.001)$, nail polish and cosmetics used by children $(P<0.001)$ were positive, indicating that these three factors were significantly positively correlated with NP concentration (Figure 5A). The other seven factors, including gender $(P=$ 0.004), feeding pattern $(P=0.047)$, plastic water cup used during pregnancy $(P=0.042)$, hair spray and perfume use for children $(P=0.019)$, duration of children birth $(P=0.002)$, materials for baby bottle or cup $(P=0.002)$ and ways to plastic products $(P=0.034)$ were significantly positively correlated with BPA concentration, indicating that these environmental factors could increase BPA concentration in serum in in school-age children (Figure 5B). Gender $(P=$ 0.038), perms used during pregnancy $(P<0.001)$, hair spray and perfume use for children $(P=0.012)$, using plastic lunch box during pregnancy $(P=0.007)$, duration of children birth $(P=0.006)$, exposure to pesticides $(P=0.008)$, parents' occupations $(P=0.041)$ were positively correlated with DMP concentrations, indicating that these environmental factors could increase DMP concentrations in children's serum (Figure $5 \mathrm{C}$ ).

\subsection{Correlations between serum EDCs (NP, BPA and DMP) concentrations and hepatic function}

\subsubsection{Effects of EDCs on serum TBIL level}

Binary logistic regression analysis of data showed the associations of serum DMP (OR: 1.371, 95\% Cl: 1.038 -1.811, $P=0.026)$ and NP $(O R: 1.344,95 \%$ Cl: $1.019-1.772, P=0.036)$ concentrations with serum TBIL level (Supplementary Table 4).

\subsubsection{Effects of EDCs on serum DBIL level}

Univariate logistic regression analysis of data showed an association of serum NP concentration (OR: $1.465,95 \%$ Cl: 1.114-1.928, $P=0.006$ ) with serum DBIL level (Supplementary Table 5).

\subsection{Data of hepatic function tests}

In 462 hepatic function assay reports, the AST level of school-age children was between 2-107 U/L, with an average of $17.926 \mathrm{U} / \mathrm{L}$; the ALT level was about 4.1-69 U/L, with an average of 27.184 U/L; the ALT/AST ratio was in 0.29-7, with an average of 1.834; the TBIL level was around 1.2-112 $\mu \mathrm{mol} / \mathrm{L}$, with an average of $10.545 \mu \mathrm{mol} / \mathrm{L}$; the DBIL level was between 0.2-10.8 $\mu \mathrm{mol} / \mathrm{L}$, with an average of $0.2 \mu \mathrm{mol} / \mathrm{L}$; The IBIL value was between 0.4-36.3 $\mu \mathrm{mol} / \mathrm{L}$, with an average of $8.161 \mu \mathrm{mol} / \mathrm{L}$ (Supplementary Table 6).

\subsection{Comparison of TBIL, DBIL and IBILlevels by gender, age and address}


The values of TBIL, DBIL and IBIL in the serum of school-age children in Zunyi were different on the gender, and the concentrations of TBIL and IBIL were different on the address. There was no statistical difference in the results of hepatic function at the age (Figure 6).

\subsection{Correlation between environmental risk factors and hepatic function}

The results of hepatic function as the dependent variable and the risk factors on the questionnaire as the independent variables, the results of the multiple linear regression analysis were shown in Table 6. Cosmetics used during pregnancy were positively correlated with ALT $(P=0.050)$ and AST $(P=0.021)$. There was a positive correlation between the frequency of hair spray and perfume use for children and the AST $(P=0.022)$ (Supplementary Table 7).

\subsection{Correlations of EDCs (NP, BPA and DMP) concentrations with hepatic function by gender, age, and address}

When the concentration of serum NP, BPA and DMP in school-age children was quartered, there was a significant difference in the association trend between NP and AST by sex $\left(P \mathbf{U}_{2}=0.031, P \mathbf{E}_{4}<0.001\right)$ (Figure 7A), and there was also a significant association between NP and ALT/AST in women $\left(P \boldsymbol{\square}_{1}<0.001, P \square_{2}=0.042, P \boldsymbol{\square}_{3}=0.009\right)$ (Figure 7B). By address, the correlation between NP and AST was significantly different in Bozhou district $\left(P \mathbf{\Delta}_{1}=\right.$ $\left.0.02, P \boldsymbol{\Delta}_{3}=0.006\right)$ (Figure 7C). The correlation between DMP and AST was also different in Bozhou district $\left(P \boldsymbol{\Delta}_{2}=\right.$ 0.003) (Figure 7D). The correlation between DMP and ALT/AST was also different in Bozhou district $\left(P \bigcirc_{2}=0.049 \rrbracket\right.$

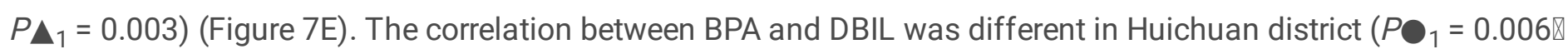
$P \mathrm{O}_{2}=0.008, P \mathrm{O}_{3}=0.007$ ) (Figure 7F). There was no difference by age.

\section{Discussion}

In the previous research on NP pollution in rivers and tap water in Zunyi city, the NP concentration in tap water in Huichuan District (industrial zone) was 6 times that of Honghuagang District (residential zone), which exceeded the standard of NP in the fresh water of U.S. EPA $(6.6 \mu \mathrm{g} / \mathrm{L})$ (Careghini et al. 2015). NP as a heat stabilizer of polyvinyl chloride (PVC), in household equipment could be released into drinking water, which contributed to the increase of concentration of NP in tap water (Jie et al. 2017). The northern part of Guizhou was a karst landform with relatively hard water. Residents usually use barrel water and bottled water for daily use. The NP easily migrated and accumulated in the human (Cheng et al. 2015; Xuesong et al. 2017). Based on the above facts, the type of drinking water in family was a significant positive cause of the accumulation concentration of NP in children's serum. Fu et al. (2008) reported the NP solubility was higher in summer than in winter (Fu et al. 2008), which coincided with this study. However, the specific reasons need to be further explored.

Trasande et al. (2013) found that there was a significant correlation between PAEs metabolites and gender. It was found that a certain dose and duration of BPA exposure could change the number of follicles and hormone production in female rats (Trasande et al. 2013). Other studies have shown that the concentration of bisphenol in urine of pregnant women was related to the increase of gestational age, suggesting that EDCs exposure would affect the duration of pregnancy (Patel et al. 2017). Veiga et al. (2018) found that prenatal exposure to BPA had an impact on the length of pregnancy and childbirth, and this effect was gender-differentiated (Veiga et al. 2018). These studies suggested that exposure of BPA and PAEs with estrogen-like effect were different in gender, and childbirth duration was related to exposure concentration. This was consistent with the conclusion that gender and childbirth duration were the main factors affecting EDCs exposure in the results of this study. It has been reported that BPA and NP could promote the production of human chorionic gonadotropin (hCG) (USCDC. 2010), and exposure to 
EDCs during pregnancy had adverse effects on offspring (Paulesu er al. 2018). NP had weak estrogen activity, and estrogen receptor (ER) could induce male infertility by negatively affecting sperm quality (Jin et al. 2013). The above studies indicated that the critical period of female womb development and the reproductive health of male partners may be affected by NP, BPA or PAEs (Liu et al. 202; Pant et al. 2014). Therefore, the frequent use of hair dye, hair spray and plastic cups during pregnancy had great influence on the concentrations of NP and DMP in fetal serum.

At present, most of the studies on the effects of NP, BPA and DMP on liver were based on animal models. It was found that NP exposure increased ALP level in rats (Rattan et al. 2017; Liu et al. 2019). In BPA-fed rats, ALP and AST levels decreased significantly, but ALT levels did not change significantly (Kazemi et al. 2016). The previous animal experiments of the research group also strongly suggested that the elevation of ALT and AST in serum was a sign of hepatic damage caused by NP (Kazemi et al. 2017). Khalil et al. (2014) reported that NP exposed to rats showed estrogen toxicity in liver and testis (Khalil et al. 2014). Huang et al. (2019) showed that perinatal exposure to 4-NP could affect the synthesis of fatty acids in the liver of $F_{1}$ and $F_{2}$ of rats offspring (Huang et al. 2019). The mechanism of biological research implied that the toxic effect of EDCs was partly caused by oxidation and inducing hepatocyte death (Mansouri et al. 2019). This was basically consistent with the results of this study, although this study only indicated a weak correlation between NP, BPA, DMP and hepatic function results.

There were few epidemiological studies regarding the effect of NP, BPA and DMP on liver. Some experts found that the increase of ALT and AST was related to PAEs exposure in the research of the potential effect of PAEs on normal hepatic function and cardiac metabolism in men (Yu et al. 2018). Previous studies have also demonstrated that in subjects over 60 years old, BPA level in urine was significantly correlated with ALT, AST, and y - GTP levels (Milošević et al. 2017; Lang et al. 2008) Meanwhile, the group with higher BPA concentration showed significant abnormality in hepatic function (OR ratio: 2.66) (Melzer et al. 2010). On the contrary, another study did not reveal a significant relationship between BPA exposure level and AST level in obese children $(\beta=1.48, P=0.12)$ (Lee et al. 2014). Lee et al. (2014) analyzed the BPA concentration in serum and serum liver level of children in all age groups, and found that the dose-correlation between them was more obvious in boys, and specially in children aged 7-9 years. In contrast, there was a sex differences in women in the level of NP and hepatic function, not in age in this study. The inconsistency may be caused by the number of samples. The number of subjects of Lee's study was only 113 . The differences in this study were not only in gender, but also in geographical distribution. The correlation between serum concentrations of NP, BPA, DMP and hepatic function were significant by address, especially in industrial zone and suburb. This may come from that the old urban area of industrial zone was an economic and political center where the catering industries was numerous, and the frequency of drinking tap water and plastic bottled water was relatively high, indicating that $\mathrm{EDC}_{\mathrm{S}}$ exposure was related to urban pollution, commercialization and urbanization, etc.

Due to the special estrogen action of EDCs, research on gender differences has been a hot topic that has been recently concerned and discussed, but no consistent conclusion has been made so far (Lee et al. 2017). At present, there were several opinions as followed: (1) there was gender difference (Di Lorenzo et al. 2002) in $E_{2}$ receptor (ERs) in hypothalamus and hippocampus (Figueiredo et al. 2002; Fitch et al. 1998). EDC could affect gender expression by changing steroid levels (androgen or 17- $\beta$ estradiol, $E_{2}$ ) and/or intracellular $E_{2}$ receptor, or acting as an agonist or antagonist of intracellular or membrane ERs (Di Lorenzo et al. 2002). (2) More and more evidences supported the theory of endogenous hormones (Kanit et al. 2000; Liu and Sun 2018). Endogenous testosterone, sex hormone binding globulin (SHBG) and thyroid binding globulin (TBG) (Liu and Sun. 2018) are hormone related biomarkers, which represent potential targets of EDCs function in human. The level of free circulating hormone was influenced by binding sex hormone receptor (Fitch and Denenberg. 1998). For example, estrogen can increase T4 binding 
globulin (TBG) concentration in the serum, thus increasing the total serum T4 concentration (Beatty. 1979; Ding et al. 2006; Ding et al. 2009). (3) Other studies have shown that EDCs with estrogen-like effect combined to estrogen receptor (Di Lorenzo et al. 2002) or through $\mathrm{E}_{2}$ plasma transporter, which has overall estrogen effect on ER and enhances the response of endogenous estrogen (Ain et al. 1987; Deyssig and Weissel. 1993). In addition, EDC may act through other homologous intracellular steroid receptors (Arafah. 1994; Kuiper et al. 1997; Hutchison. 1997; Hotchkiss et al. 2002). EDCs' gender differences is more complicated, and further studies are need to be done.

Perinatal exposure to NP could interfere with estrogen and progesterone levels in pregnant rats, cause changes in hepatic structure and function in neonatal rats, and lead to threatened abortion and dystocia (Meng et al. 2019). Other studies have shown that the exposure of perinatal mice to BPA would damage the antioxidant defense system of female mice, cause oxidative damage to the liver, and contribute to metabolic disorders (Meng et al. 2019). Submicro BPA could induce human liver cell proliferation and DNA damage in vitro experiments, and was an important risk factor for liver cancer (Kim et al. 2018). The maternal perinatal exposure to NP, BPA, DMP had adverse effects on the hepatic function of the offspring, which was consistent with previous experiment. This study directly firstly calculated the direct risk factors for mother' exposure during pregnancy and school-age children: frequency of using cosmetics during pregnancy and the frequency of children using hairspray and perfume. No related research has been reported before, and so further researches are needed be done.

There are some shortcomings in this study. First, the design of this study was only a cross-sectional design, and a forward-looking longitudinal study is needed to be continued. Second, questionnaire is susceptible to a bias.

\section{Conclusion}

School-age children aged 5-14 years in northern Guizhou have been generally exposed to the pollution of NP, BPA, and DMP, which were closely related to the environmental risk factors of maternal exposure during pregnancy, infancy and school age. The association between their exposure and adverse effects on hepatic function was apparent in children. Among environmental risk factors, the number of times the mothers used cosmetics during pregnancy, and the number of times that school-age children used hair gels and perfumes had a greater impact on hepatic function damage. These high levels of exposure should further be reduced through lifestyle changes. There are currently few studies about population research, and further epidemiological investigations should be conducted to to reduce children's exposure to NP, BPA, and DMP as soon as possible.

\section{Declarations}

\section{Acknowledgements}

Not applicable.

\section{Funding}

This work was supported by the National Natural Science Foundation of China (81760580); the Key Program of Scientific and Technological Fund of Department of Science and Technology of Guizhou Province, China (20191466; 2018-1429); the Scientific and Technological Talent Support Program of the Educational Commission of Guizhou Province of China (KY[2018]054); 15851 Project Talent in Zunyi municipal government, Guizhou Province (2017, 2018(E-262)). Guizhou High-Level Innovative Talent Support Program ([2020]6014).

\section{Availability of data and materials}

Page 15/31 
The datasets used and/or analyzed during the current study available from the corresponding author on reasonable request.

\section{Contributions}

Jie Xu and Jie Yu designed the study. Xiangjun Fu, Deliang Zheng, Xuefeng Yang, Pan Wang, Jie Yu and Jie Xu analyzed and interpreted the data. Xiangjun Fu, Jie Yu and Jie Xu are responsible for designing and revising the questionnaire. Xiangjun Fu, FangXu Tuo, Lin Wang, Shixu Li and Jie Yu participated in the investigation. Jie Yu and Xiangjun Fu wrote the manuscript, Jie Xu revised the manuscript.

\section{Consent for publication}

All the authors read and approved this paper.

\section{Ethics statement}

The Ethics Committee of the Zunyi Medical University approved the study (2015-1-017). All methods were performed in accordance with guidelines and regulations of the Zunyi Medical University.

\section{Competing interests}

The authors declare that they have no competing interests.

\section{References}

1. Ain KB, Mori Y, Refetoff S.1987. Reduced clearance rate of thyroxine-binding globulin (TBG) with increased sialytion: a mechanism for estrogen-induced elevation of serum TBG concentration.J Clin Endocrinol Metab 65:689-696.

2. Arafah BM.1994.Decreased levothyroxine requirement in women with hypothyroidism during androgenic therapy for breast cancer. Ann Intern Med 121:247-251.

3. Bergman Å, Becher G, Blumberg B, Bjerregaard P, Bornman R, Brandt I, Casey SC, Frouin H, Giudice LC, Heindel JJ, Jobling S, Kidd KA, Kortenkamp A, Lind PM, Muir D, Ochieng R, Ropstad E, Ross PS, Skakkebaek NE, Toppari J,Vandenberg LN, Woodruff TJ, Zoeller RT. 2015.Manufacturing doubt about endocrine disrupter science--A rebuttal of industry-sponsored critical comments on the UNEP/WHO report "State of the Science of Endocrine Disrupting Chemicals 2012".Regul Toxicol Pharmacol 73:1007-17.

4. Balakrishnan B, Henare K, Thorstensen EB, Ponnampalam AP, Mitchell MD.2010. Transfer of bisphenol A across the human placenta. Am J Obstet Gynecol 202:393-397.

5. Braun JM, Kalkbrenner AE, Just AC, Yolton K, Calafat AM, Sjödin A, Hauser R,Webster GM, Chen A, Lanphear BP.2014.Gestational exposure to endocrine disrupting chemicals and reciprocal social, repetitive, and stereotypic behaviors in 4-and 5-year-old children:The home study.Environ Health Perspect 5:513-520.

6. Bloom MS, Kim D, Vom Saal FS, Lamb JD, Fujimoto VY.2011. Bisphenol A exposure reduces the estradiol response to gonadotropin stimulation during in vitro fertilization. Fertil Steril 96:672-677.

7. Bloom MS, Vom Saal FS, Kim D,Taylor JA,Lamb JD, Fujimoto VY.2011. Serum unconjugated bisphenol A concentrations in men may inflfuence embryo quality indicators during in vitro fertilization. Environ Toxicol Pharmacol 32:319-23. 
8. Brucker-Davis F, Ferrari P, Boda-Buccino M.2011. Cord blood thyroid tests in boys born with and without cryptorchidism: correlations withbirthparameters andinutero xenobiotics exposure. Thyroid 21:1133-1141.

9. Beatty WW.1979.Gonadal hormones and sex differences in nonreproductive behaviors in rodents: Organizational and activational influences. Hormones and Behavio 12:112-163.

10. Careghini A, Mastorgio AF, Saponaro S, Sezenna E.2015.Bisphenol A, nonylphenols, benzophenones, and benzotriazoles in soils, groundwater, surface water, sediments, and food: a review. Environ Sci Pollut Res 22:5711-5741.

11. CDC (Centers for disease control and prevention).2103.biomonitoring summary: bisphenol $A$. Available:http://www.cdc.gov/nchs/nhanes.htm[accessed 2016].

12. Cai depei.2013. Research progress on environ mental endocrine disruptors leading to child dysplasia. Shanghai med 2:3-5.

13. Cobellis L, Colacurci N, Trabucco E, Carpentiero C, Grumetto L.2009. Measurement of bisphenol A and bisphenol B levels in human blood sera from healthy and endometriotic women.Biomed Chromatogr 23:1186-90.

14. Chou WC, Chen JL, Lin CF,Shih FC, Chuang CY.2011. Biomonitoring of bisphenol A concentrations in maternal and umbilical cord blood in regard to birth outcomes and adipokine expression: a birth cohort study in Taiwan. Environ Health 10:94.

15. Careghini A, Mastorgio A F, Saponaro S, Sezenna E.2015. Bisphenol A, nonylphenols, benzophenones, and benzotriazoles in soils, groundwater, surface water, sediments, and food: a review.Environ Sci Pollut Res Int 22:5711-5741.

16. Cheng YC, Chen HW, Chen WL,Chen CY, Wang GS.2015. Occurrence of nonylphenol and bisphenol A in household water pipes made of different materials. Environ Monit 188:562.

17. Collaer ML,Hines M.1995.Human behavioral sex differences: A role for gonadal hormones during early development? Psychological Bulletin 118:55-107.

18. Dai juanjuan.2014. Analysis of phthalate metabolites in urine and its correlation with childhood obesity. Shanghai: Shanghai jiao tong university 52.

19. Dirtu AC, Roosens L, Geens T.2008. Simultaneous determination of bisphenol A, triclosan, and tetrabromobisphenol $A$ in human serum using solid-phase extraction and gaschromatography-electron capture negative-ionization mass spectrometry.Anal BioAnal Chem 391:1175-1181

20. Di Lorenzo D, Villa R, Biasiotto G,Belloli S,Ruggeri G,Albertini A.2002.Isomer-specific activity of dichlorodyphenyltrichloroethane with estrogen receptor in adult and suckling estrogen reporter mice. Endocrinology 143:4544-4551.

21. Ding EL, Song Y, Malik VS, Liu S.2006.Sex differences of endogenous sex hormones and risk of type 2 diabetes: A systematic review and meta-analysis. JAMA 295:1288-1299.

22. Ding EL, Song Y,Manson JE,Hunter DJ,Lee CC,Rifai N,Buring JE,Gaziano JM,Liu S.2009. Sex hormone-binding globulin and risk of type 2 diabetes in women and men. N Eng J Med 361: 1152-1163

23. Deyssig R,Weissel M.1993.Ingestion of androgenic-anabolic steroids induces mild thyroidal impairment in male body builders.J Clin Endocrinol Metab 76:1069-1071.

24. European Commission(EU) on plastic mfl-terials and articles intended to come into contact with food [J]. $\mathrm{m}$

25. Fisher BG, Frederiksen H, Andersson AM, Juul A, Thankamony A, Ong KK, Dunger DB, Hughes IA, Acerini CL.2018. Serum phthalate and triclosan levels have opposing associations with risk factors for gestational diabetes mellitus. Front Endocrinol (Lausanne) 9:99. 
26. Frederiksen H, Jorgensen N, Andersson AM.2010. Correlations between phthalate metabolites in urine, serum, and seminal plasma from young Danish men determined by isotope dilution liquid chromatography tandem mass spectrometry.J Anal Toxicol 34:400-410.

27. Fujimoto VY, Kim D, vom Saal FS.2011. Serum unconjugated bisphenol A concentrations in women may adversely in flfluence oocyte quality during in vitro fertilization. Fert Steri 95:1816-1819.

28. Fenichel P, Dechaux H, Harthe C.2012. Unconjugated bisphenol A cord blood levels in boys with descended or undescended testes. Hum Reprod 27:983-90.

29. FFDA (Federal Food and Drug Administration).2014.Guidance for industry:preparation of food contact notifications for food contact substa-nces:toxicology reeommendations 22:15-22.

30. Fu M, Li Z, Gao H. 2008.Distribution characteristics of nonylphenol in Jiaozhou Bay of Qingdao and its adjacent rivers.Chemosphere 69:1009-1016.

31. Figueiredo HF,Dolgas CM,Herman JP.2002.Stress activation of cortex and hippocampus is modulated by sex and stage of estrus. Endocrinology 143:2534-2540.

32. Fitch RH,Denenberg VH.1998.A role for ovarian hormones in sexual differentiation of the brain. Behavioral and Brain Sciences 21,311-327.

33. Frye CA.2001.The role of neurosteroids and non-genomic effects of progestins and androgens in mediating sexual receptivity of rodents.Brain Research Reviews37: 201-222.

34. Gore AC, Chappell VA, Fenton SE,Flaws JA, Nadal A, Prins GS, Toppari J,Zoeller RT.2015. EDC-2: the endocrine society's second scientific statement on endocrine-disrupting chemicals. Endocr Rev 36:1-150.

35. Gyllenhammar I, Glynn A, Darnerud PO,Lignell S. 2012.4-Nonylphenol and bisphenol A in Swedish food and exposure in Swedish nursing women. Environ Int 43:24-28.

36. Goodman M, Lakind J S, Mattison D R. 2014.Do phthalates act as obesogens in humans? A systematic review of the epidemiological literature. Crit Rev Toxicol 44:151-175.

37. Guo Y, Zhang Z, Liu L, Li Y, Ren N, Kannan K.2012. Occurrence and profiles of phthalates infoodstuffs from China and their implications for human exposure.J Agric Food Chem 60:6913-9

38. Hu J, Yang S, Wang Y,Goswami R, Peng C, Gao R, Zhou H, Zhang Y, Cheng Q,Zhen Q, Li Q.2015. Serum bisphenol A and progression of type 2 diabetic nephropathy: a 6-year prospective study. Acta Diabetol 52: 1135-1141.

39. He Y, Miao M, Herrinton LJ, Zhou Z, Li DK.2009. Bisphenol A levels in blood and urine in a Chinese population and the personal factors affecting the levels. Environ Res 109:629-633.

40. Högberg J, Hanberg A, Berglund M,Appelgren M, Håkansson H.2008. Phthalate diesters and their metabolites in human breast milk, blood or serum, and urine as biomarkers of exposure in vulnerable populations. Environ Health Perspect 116:334-339.

41. Hiroi H, Tsutsumi O, Takeuchi T, Momoeda M, Ikezuki Y,Taketani Y.2004. Differences in serum bisphenol a concentrations in premenopausal normal women and women with endometrial hyperplasia. Endocr J 51:595600.

42. Hanna CW, Bloom MS, RobinsonWP.2012. DNA methylation changes in whole blood is associated with exposure to the environmental contaminants,mercury, lead, cadmiumand bisphenolA, in women undergoing ovarian stimulation for IVF. Hum Reprod 27:1401-1410.

43. Hatch EE, Nelson JW, Stahlhut, RW,Webster TF.2010.Association of endocrine disruptors and obesity: perspectives from epidemiological studies. Int J Androl 33:324-332.

Page $18 / 31$ 
44. Huang Q, Bu L, Yang T, Yang Y, Huang S, Yang J, Guo Y, Liu C.2019.Effects of nonylphenol administration on serum, liver and testis estrogen metabolism. Chemosphere 235:543-549.

45. Hotchkiss AK,Ostby JS,Vandenburgh JG,Gray LE,2002.Androgens and environmental antiandrogens affect reproductive development and play behavior in the Sprague-Dawley rat. Environmental Health Perspectives 110:435-439.

46. Hutchison JB.1997.Gender-specific steroid metabolism in neural differentiation. Cellular and Molecular Neurobiology 17:603-626.

47. Jie X, Yang W, Jie Y.2010. Immune effects of nonylphenol on ffspring of rats exposed during pregnancy. Hum Ecol Risk Assess An Int J 16:444-452.

48. Jie X, Yang W, Jie Y, Hashim JH, Liu XY, Fan QY, Yan L.2010.Toxic effect of estational exposure to nonylphenol on f1 male rats. Birth Defects Res B Dev Reprod Toxicol89:418-428.

49. Jie Y, Fan QY, Binli H,Binli H, Biao Z, Zheng F, Jianmei L, Jie X. 2013.Joint neurodevelopmental and behavioral effects of nonylphenol and estradiol on F1 male rats. Int J Environ Health Res 23:321-330

50. Jie Y, Jie Z, Ya L, Xuesong Y, Jing Y, Yu Y, Jiaqi Y, Jie X.2017.Pollution by Nonylphenol in river, tap water, and aquatic in an acid rain-plagued city in southwest China.Int J Environ Health Res 27:179-190.

51. Jin P, Wang X, Chang F,Bai Y, Li Y, Zhou R, Chen L.2013.Low dose bisphenol A impairs spermatogenesis by suppressing reproductive hormone production and promoting germ cell apoptosis in adult rats. J Biomed Res 27(2): 135-44.

52. Jiang Y, Xia W, Zhu Y, Li X, Wang D, Liu J, Chang H, Li G, Xu B, Chen X, Li Y, Xu S.2014. Mitochondrial dysfunction in early life resulted from perinatal bisphenol A exposure contributes to hepatic steatosis in rat off spring. Toxicol Lett 228:85-92.

53. Koch HM, Kolossa-Gehring M, Schröter-Kermani C, Angerer J, Brüning T. 2012.Bisphenol A in $24 \mathrm{~h}$ urine and plasma samples of the German Environmental Specimen Bank from 1995 to 2009: a retrospective exposure evaluation. J Expo Sci Environ Epidemiol 22:610-616.

54. Kandaraki E, Chatzigeorgiou A, Livadas S, Palioura E, Economou F,Koutsilieris M, Palimeri S, Panidis D, Diamanti-Kandarakis E.2011. Endocrine disruptors and polycystic ovary syndrome (PCOS): elevated serum levels of bisphenol A in women with PCOS. J Clin Endocrinol Metab 96:480-484.

55. Konieczna A, Rachoń D, Owczarek K, Kubica P, Kowalewska A, Kudłak B, Wasik A,

56. Namieśnik J.2018. Serum bisphenol A concentrations correlate with serum testosterone levels in women with polycystic ovary syndrome. Reprod Toxicol 82: 32-37.

57. Kaddar N, Bendridi N, Harthé C, de Ravel MR, Bienvenu AL, Cuilleron CY,Mappus E, Pugeat M, Déchaud H.2009. Development of a radioimmunoassay for the measurement of Bisphenol A in biological samples. Anal Chim Acta 645:1-4.

58. Kazemi S, Mousavi Kani S N, Ghasemi-Kasman M, Aghapour F, Khorasani H,

59. Moghadamnia AA.2016. Nonylphenol induces liver toxicity and oxidative stress in rat. Biochem Biophys Res Commun 479:17-21.

60. Kazemi S, Kani S N M, Rezazadeh L,Moghadamnia AA.2017. Low dose administration of Bisphenol A induces liver toxicity in adult rats. Biochem Biophys Res Commun 494(1):519-523.

61. Khalil N,Ebert JR,Wang L.2014.Bisphenol A and cardiometabolic risk factors in obese children. Sci Total Environ 470-471:726-732. 
62. Kanit L,Taskiran D,Yilmaz OA,Balkan B,Demirgoren S,Furedy JJ.2000.Sexually dimorphic cognitive style in rats emerges after puberty. Brain Research Bulletin 52:243-248.

63. Kuiper GG,Carlsson B,Grandien K,Enmark E,Haggblad J,Nilsson S.1997.Comparison of the ligand binding specificity and transcript tissue distribution of estrogen receptors alpha and beta.Endocrinology 138:863-870.

64. Kim S, Mun GI, Choi E, Kim M, Jeong JS, Kang KW, Jee S, Lim KM, Lee YS.2018. Submicromolar bisphenol A induces proliferation and DNA damage in human hepatocyte cell lines in vitro and in juvenile rats in vivo. Food Chem Toxico 111:125-132.

65. Larsson K囚Ljung BK『Palm B囚Wennberg M, Kaj L, Lindh CH, JönssonBA, Berglund M. 2104.Exposure determinants of phthalates $₫$ parabens $₫$ bisphenol $A$ and triclosan in Swedish mothers and their children. Environ Int 73: 323-333.

66. Li S, Dai J, Zhang L, Zhang J, Zhang Z, Chen B.2011.An association of elevated serum prolactin with phthalate exposure in adult men. Biomed Environ Sci 24:31-39.

67. Li Chen.2013. Evaluation of Phthalates Exposure in China and the Mechanism of DINP Affecting Asthma Attacks. Shanghai: Fudan University.

68. Liu T, Cao W, Di Q, Zhao M, Xu Q.2109. Evaluation of toxicokinetics of nonylphenol in the adult female SpragueDawley rats using a physiologically based toxicokinetic model.Regul Toxicol Pharmacol 105: 42-50.

69. Luo Ya, Zheng Guobo, Yang Xuefeng.2016. Detection and analysis of nonylphenol load in serum of patients with type 2 diabetes mellitus. Practical Med 32:2227-2230.

70. Liu M, Hashi Y, Pan F, Yao J, Song G, Lin JM.2006. Automated on-line liquid chromatrography-photodiode arraymass spectrometry method with dilution line for the determination of bisphenol $A$ and 4-octylphenol in serum. $J$ Chromatogr $A_{\Perp}, 1133: 142-148$.

71. Larsson K, Ljung Björklund K, Palm B, Wennberg M, Kaj L, Lindh CH, Jönsson BA, Berglund M.2014. Exposure determinants of phthalates, parabens, bisphenol $A$ and triclosan in Swedish mothers and their children. Environ Int 73:323-33.

72. Lin S , Ku H Y , Su P H.2011. Phthalate exposure in pregnant women and their children in central Taiwan. Chemosphere 82:947-955.

73. Luo Y, Yu J, Yang M, Wang P, Yang C, Xu J.2019. Identification of Nonylphenol and Glucolipid MetabolismRelated Proteins in the Serum of Type 2 Diabetes Patients. Iran J Public Health 48:2210-2215.

74. Liu L, Bao H, Liu F,Zhang J, Shen H.2012. Phthalate exposure of Chinese reproductive age couples and its effects on male semen quality, a primary study. Environ Int 42:78-83.

75. Liu T, Cao W, Di Q, Zhao M, Xu Q.2019.Evaluation of toxicokinetics of nonylphenol in the adult female SpragueDawley rats using a physiologically based toxicokinetic model.Regul Toxicol. Pharmacol 105: 42-50.

76. Lang IA, Galloway TS,Scarlett A.2008. Association of urinary bisphenol A concentration with medical disorders and laboratory abnormalities in adults. JAMA 300:1303-1310.

77. Lee MR, Park H,Bae S. 2014.Urinary bisphenol A concentrations are associated with abnormal liver function in the elderly: a repeated panel study. J Epidemiol Community Health 68:312-317

78. Lee S, Lee H A, Park B,Ha EH, Park H.2017. A prospective cohort study of the association between bisphenol A exposure and the serum levels of liver enzymes in children.Environmental Research 161:195-201.

79. Liu S, Sun Q.2018.Sex differences, endogenous sex-hormone hormones, sex-hormone binding globulin, and exogenous disruptors in diabetes and related metabolic outcomes. JDiabetes 10:428-441. 
80. Mao Z, Zheng X F , Zhang Y Q ,Zhang YQ, Tao XX, Li Y, Wang W. 2012.Occurrence and biodegradation of nonylphenol in the environment.Int J Mol Sci 13:491-505.

81. Mose T, Knudsen LE, Hedegaard M,Mortensen GK.2007. Transplacental transfer of monomethyl phthalate and mono (2-ethylhexyl) phthalate in a human placenta perfusion system. Int J Toxicol 26:221-229.

82. Maserejian NN, Shrader P, Trachtenberg FL, Hauser R, Bellinger DC, Tavares M.2014.De ntal sealants and flowable composite restorations and psychosocial, neuropsychological, and physical development in children .Pediatr Dent 1:68-75.

83. Minatoya M, Itoh S, Yamazaki K, Araki A, Miyashita C, Tamura N, Yamamoto J, Onoda Y, Ogasawara K, Matsumura T, Kishi R.2018. Prenatal exposure to bisphenol A and phthalates and behavioral problems in children at preschool age: the Hokkaido Study on Environment and Children's Health. Environ Health Prev Med 23:43-47.

84. Mansouri V, Ebrahimpour K, Poursafa P, Riahi R, Shoshtari-Yeganeh B, Hystad P, Kelishadi R.2019. Exposure to phthalates and bisphenol $A$ is associated with higher risk of cardiometabolic impairment in normal weight children.Environ Sci Pollut Res Int 26: 18604-18614.

85. Milošević N, Milić N, Živanović Bosić D, Bajkin I, Perčić I, Abenavoli L,Medić Stojanoska M.2017.Potential influence of the phthalates on normal liver function and cardiometabolic risk in males. Environ Monit Assess 190:17-23.

86. Melzer D,Rice NE,Lewis C.2010.Association of urinary bisphenol A concentration with heart disease: evidence from NHANES 2003/06. PLoS One 5:8673.

87. Min J, Han J, Kim K, Park S, Lee S, Hong J, Gil H, Song H, Hong S.2017. Human cholestatic hepatitis owing to polyoxyethylene nonylphenol ingestion: A case report.Medicine (Baltimore) 96: 7737.

88. Meng Z,Tian S , Yan J,Yan S, Li R, Zhang R, Zhu W, Zhou Z.2019.Effects of perinatal exposure to BPA, BPF and BPAF on liver function in male mouse offspring involving in oxidative damage and metabolic disorder.

Environmental Pollution 247:935-943.

89. NIEHS(National Institute of Environmental Health Science).2010.Endocrine disruptors fact sheet,A vailable.Available:http://cerhe.niehs.nih.gov/[accwssed May 2010].

90. Owczarek K, Kubica P, Kudłak B.2018. Determination of trace levels of eleven bisphenol A analogues in human blood serum by high performance liquid chromatographytandem mass spectrometry. Sci Total Environ 1:628629.

91. Pisapia L, Del Pozzo G, Barba P, Caputo L, Mita L, Viggiano E, Russo GL,Nicolucci C, Rossi S, Bencivenga U, Mita DG, Diano N.2012.Effects of some endocrine disruptors on cell cycle progression and murine dendritic cell differentiation. Gen Comp Endocrinol 178:54-63.

92. Padmanabhan V, Siefert K, Ransom S, Tao L, Kannan K.2008. Maternal bisphenol-A levels at delivery: a looming problem. J Perinatol 28:258-263.

93. Patel S, Brehm E, Gao L, Rattan S, Ziv-Gal A, Flaws JA.2107. Bisphenol a exposure, ovarian follicle numbers, and female sex steroid hormone levels: Results from a CLARITY-BPA Study. Endocrinology 158:1727-1738.

94. Paulesu L, Rao CV, letta F, Pietropolli A, Ticconi C.2018.hCG and its disruption by environmental contaminants during human pregnancy.Int J Mol Sci 19:914-915.

95. Pant N, Kumar G, Upadhyay AD,Patel DK, Gupta YK, Chaturvedi PK.2014. Reproductive toxicity of lead, cadmium, and phthalate exposure in men.Environ Sci Pollut Res Int 21:11066-11074.

96. Qiao L, Zheng L, Cai D.2010. Study on the levels of the bisphenol A, octylphenol, 4-nonylphenol in serum of precocious girls. Journal of hygiene research 39:9-12. 
97. Qiao L, Zheng L, Cai D.2010. Determination and analysis of bisphenol A, octylphenol and 4-nonylphenol in serum of precocious puberty girls. Health research 39:9-12.

98. Rezg R, El-Fazaa S, Gharbi N, Mornagui B.2104.Bisphenol A and human chronic diseases:current evidences, possible mechanisms, and future perspectives. Environ Int 64:83-90.

99. Rattan S, Zhou C, Chiang C, Mahalingam S, Brehm E, Flaws JA.2017. Exposure to endocrine disruptors during adulthood: consequences for female fertility. J Endocrinol 233:109-129.

100. Song S , Duan Y, Zhang T ,Zhang B, Zhao Z, Bai X, Xie L, He Y, Ouyang JP,Huang X, Sun H.2019. Serum concentrations of bisphenol $A$ and its alternatives in elderly population living around e-waste recycling facilities in China: Associations with fasting blood glucose. Ecotoxicol Environ Saf 169:822-828.

101. Senthil Kumaran S, Kavitha C, Ramesh M, Grummt T.2011. Toxicity studies of nonylphenol and octylphenol: hormonal, hematological and biochemical effects in Clarias gariepinus. J Appl Toxicol 31:752-761.

102. Szybiak A, Rutkowska A, Wilczewska K, Wasik A, Namieśnik J, Rachoń D.2017. Daily diet containing canned products significantly increases serum concentrations of endocrine disruptor bisphenol $A$ in young women.Pol Arch Intern Med 127:278-280.

103. Specht IO, Toft G, Hougaard KS, Lindh CH, Lenters V, Jönsson BA, Heederik D,

104. Giwercman A, Bonde JP.2104. Associations between serum phthalates and biomarkers of reproductive function in 589 adult men.Environ Int 66:146-156.

105. Shekhar S, Sood S, Showkat S,Lite C, Chandrasekhar A.2107. Detection of phenolic endocrine disrupting chemicals (EDCs) from maternal blood plasma and amniotic fluid in Indian population. Gen Comp Endocrinol 241:100-107.

106. Shu X, Tang S, Peng C.2018. Bisphenol A is not associated with a 5-year incidence of type 2 diabetes: a prospective nested case-control study. Acta Diabetol 55:369-375.

107. Singh A.R., W.H. Lawrence, J. Autian. 1972. Teratogenicity of phthalate esters in rats. J. Pharm. Sci., 61(11:5155.

108. Sugiura-Ogasawara M, Ozaki Y, Sonta S, Makino T, Suzumori K. 2005. Exposure to bisphenol A is associated with recurrent miscarriage. Hum Reprod 20:2325-2329

109. Song S, Duan Y , Zhang T,Zhang B, Zhao Z,Huang X, Sun H.2019. Serum concentrations of bisphenol A and its alternatives in elderly population living around e-waste recycling facilities in China: Associations with fasting blood glucose. Ecotoxicol Environ Saf 169:822-828.

110. Shenying Feng, Yuying Ruan, Chunmei Gao.1995. A preliminary study on phthalates in the atmosphere of Hohhot. Shanghai Environmental Science 6:35-46.

111. Takeuchi T, Tsutsumi O, Ikezuki Y, Takai Y, Taketani Y.2004. Positive relationship between androgen and the endocrine disruptor, bisphenol A, in normal women and women with ovarian dysfunction. Endocrine J 51:165169.

112. Takeuchi T, Tsutsumi O. 2002.Serumbisphenol a concentrations showed gender differences, possibly linked to androgen levels. Biochem Biophys Res Commun 291:76-78.

113. Tarantino G, Valentino R, Di Somma C, D'Esposito V,Savastano S.2013. Bisphenol A in polycystic ovary syndrome and its association with liverspleen axis. Clin Endocrinol (Oxf) 78:447-53.

114. Trasande L, Sathyanarayana S, Spanier A J.2013.Urinary phthalates are associated with higher blood pressure in childhood. J Pediatr 163:747-753.

115. United States Congress. 2014.Pub L No 75-717 food, drug, and cosmetic act 23:95-99

Page 22/31 
116. U.S.A. Centers for Disease Control Prevention (USCDC). 2010.National Report on Human Exposure to Environmental Chemicals cosmetic 258-277

117. Volkel W, Bittner N, Dekant W. 2005.Quantitation of bisphenol A and bisphenol A glucuronide in biological samples by high performance liquid chromatography-tandem mass spectrometry. Drug Metab Dispos 33:17481757.

118. Veiga-Lopez A, Kannan K, Liao C, Ye W, Domino SE, Padmanabhan V.2105. Gender-Specific Effects on Gestational Length and Birth Weight by Early Pregnancy BPA Exposure.J Clin Endocrinol Metab 100:1394-403.

119. Wang Y, Zhu H, Kannan K. 2019.A review of biomonitoring of phthalate exposures.Toxics. 7:21.

120. Wang W, Zhang Y, Wang S, Fan CQ, Xu H.2012. Distributions of phthalic esters carried by total suspended particulates in Nanjing, China.Environ Monit Assess 184:6789-98.

121. Wan Y, Huo W, Xu S.2018.Relationship between maternal exposure to bisphenol S and pregnancy duration. Environmental Pollution 238:717-724.

122. Xie C, Zhao Y, Gao L, Chen J, Cai D, Zhang Y. 2015.Elevated phthalates' exposure in children with constitutional delay of growth and puberty. Mol Cell Endocrinol 407:67-73.

123. Xiao Q, Li Y, Ouyang H, Xu P, Wu D.2006. High-performance liquid chromatographic analysis of bisphenol $A$ and 4-nonylphenol in serum, liver and testis tissues after oral administration to rats and its application to toxicokinetic study. J Chromatogr B Analyt Technol Biomed Life Sci 830: 322-329.

124. Xiao GB, Wang RY, Cai YZ.2009. Effect of bisphenol A on semen quality of exposed workers: a pilot study.Chinese J Ind Hyg Occ Dis 27:741-743.

125. Xuesong Y, Jie Z, Jie Y.Jing Y, Jie X.2107.Current status of nonylphenol pollution in a river in southwest China. Shanxi medical journal 46:2155-2157.

126. Yu J,Li K, Tang Y, Xu J.2016.Prevalence of asthma and asthma-related symptoms among adults who exposed to indoor environmental risk factors: A comparison between winter and summer in Zunyi, China. Polish Journal of Environmental Studies 25:621-633.

127. Yu J, Luo Y, Yang XF, Yang MX, Yang J, Yang XS, Zhou J, Gao F, He LT, Xu J.2016. Effects of perinatal exposure to nonylphenol on delivery outcomes of pregnant rats and inflammatory hepatic injury in newborn rats.Braz $\mathrm{J}$ Med Biol Res 49: 5647.

128. Yu J, Yang X, Yang X, Yang M, Wang P, Yang Y, Yang J, Li W, Xu J.2018. Nonylphenol aggravates non-alcoholic fatty liver disease in high sucrose-high fat diet-treated rats.Sci Rep 8:3232.

129. Yu J, Luo Y, Yang XF,Yang J, Yang XS,He LT, Xu J.2016. Effects of perinatal exposure to nonylphenol on delivery outcomes of pregnant rats and inflammatory hepatic injury in newborn rats.Braz J Med Biol Res 49:5647.

130. Yu Y,Jie Z, Xuesong Y.2107. Investigation on nonylphenol content in bottled water and bottled water. Modern medicine hygiene 33:1457-1462.

131. Yang M, Ryu JH, Jeon R, Kang D, Yoo KY.2009. Effects of bisphenol A on breast cancer and its risk factors. Arch Toxico 83:281-285.

132. Zhou J, Henriquez J, Crawford R, Kaminski N.2018. Suppression of the IgM response by aryl hydrocarbon receptor activation in human primary B cells involves impairment of immunoglobulin secretory processes. Toxicol Sci 163:319-329.

133. Zheng YM, Wang Y, Zhao J.2012. Association between serum bisphenol-A and recurrent spontaneous abortion: a 1:2 case-control study China.Zhonghua Liu Xing Bing Xue Za Zhi 33:841-845. 
134. Zhang Z, Alomirah H, Cho HS,Li YF, Liao C, Minh TB, Mohd MA, Nakata H, Ren N, Kannan K.2011.Urinary bisphenol A concentrations and their implications for human exposure in several Asian countries. Environ Sci Technol 45:7044-7050.

\section{Figures}
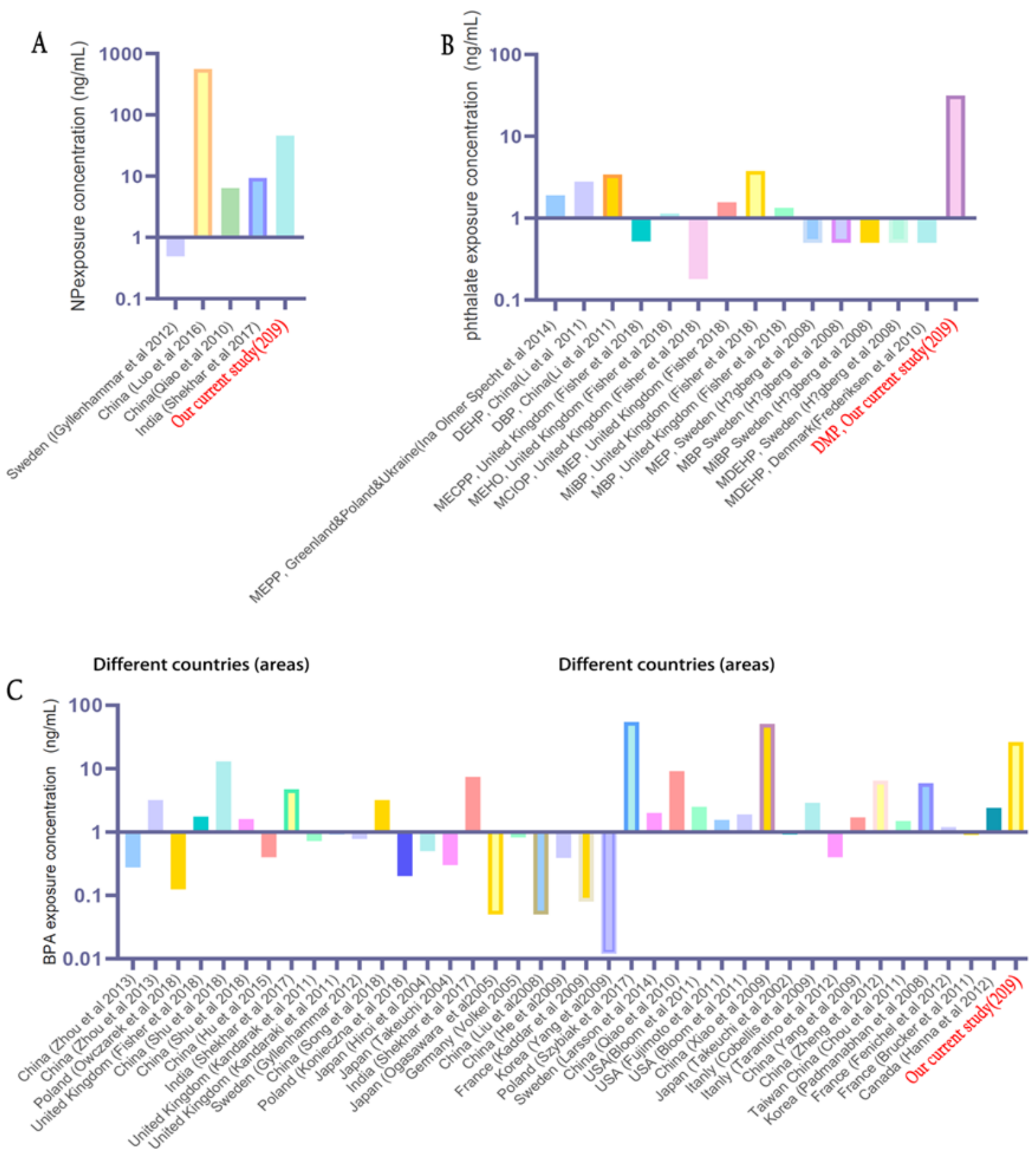

Different countries (areas)

\section{Figure 1}

Comparison of concentrations of three EDCs (NP, BPA and PAE) measured in different countries (areas). A『NP concentration; B囚DMP concentration; CबBPA concentration. The exposure values in the vertical coordinate in these figures are obtained from the original concentration in the literature was log-transformed. 


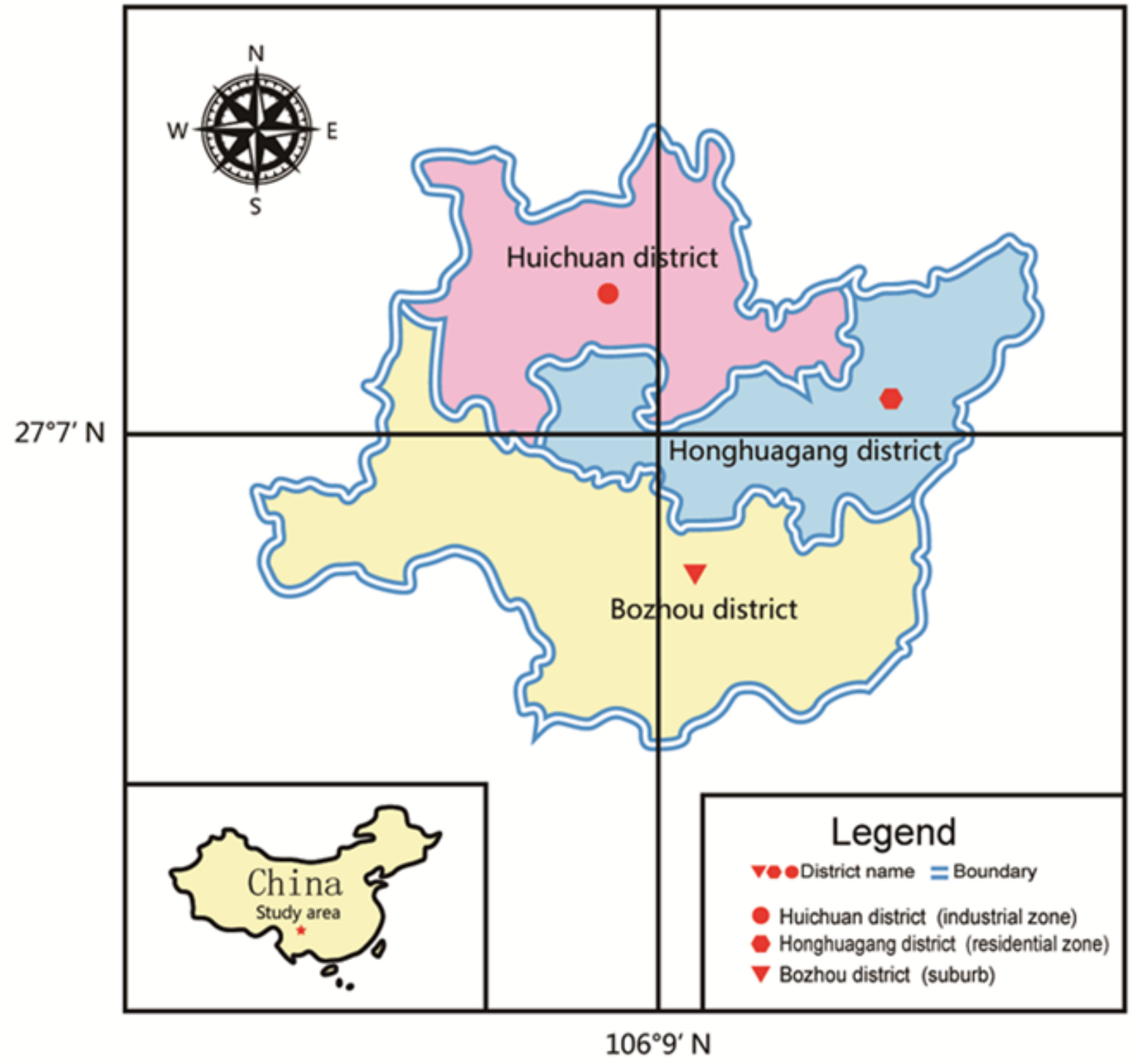

\section{Figure 2}

Study location. Note: The designations employed and the presentation of the material on this map do not imply the expression of any opinion whatsoever on the part of Research Square concerning the legal status of any country, territory, city or area or of its authorities, or concerning the delimitation of its frontiers or boundaries. This map has been provided by the authors. 
Aerial respiration, Skin contact, and Digestive tract absorption

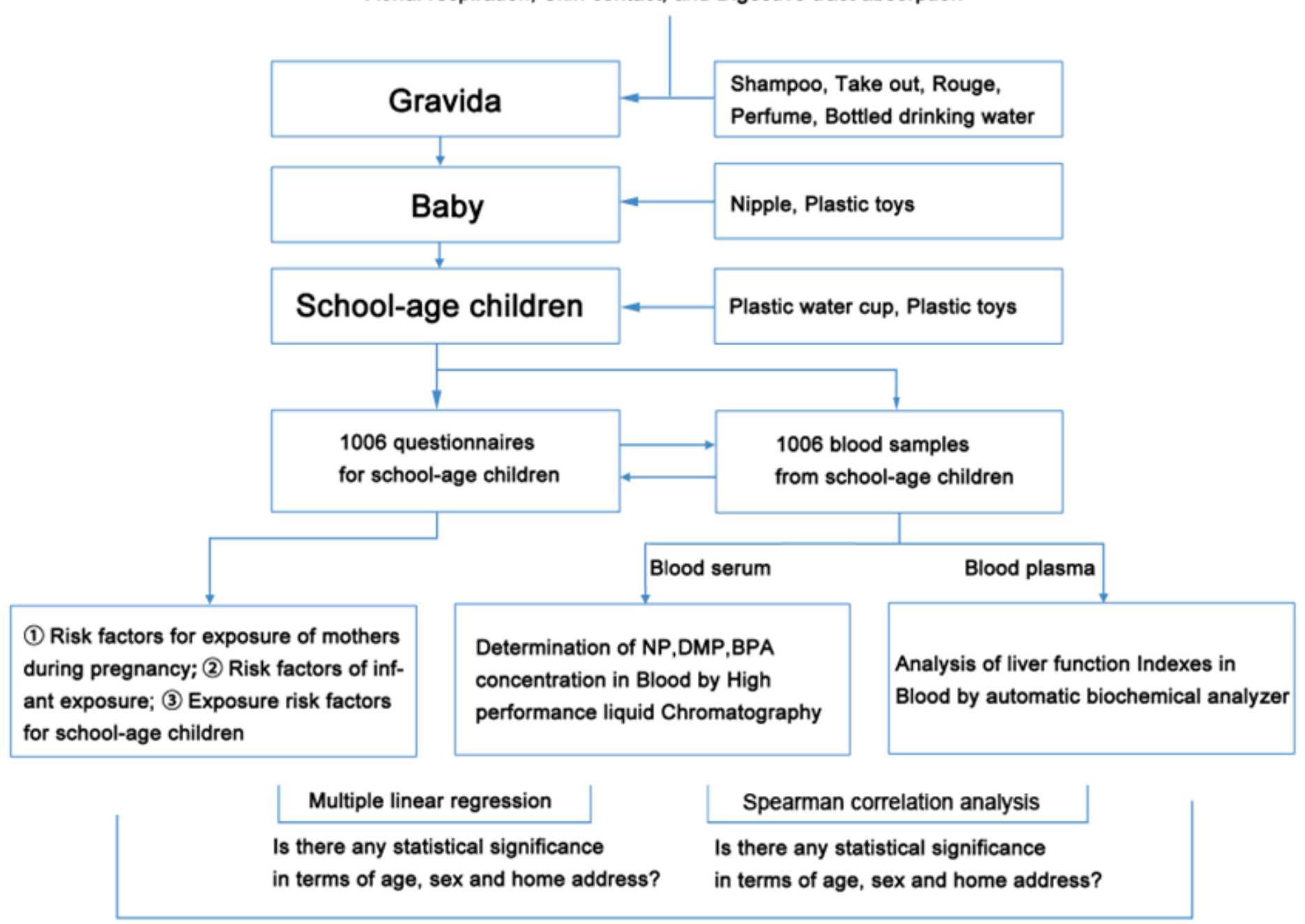

Multiple linear regression

Figure 3

Flowchart depicting exposure protocols and selection process of the participants. 

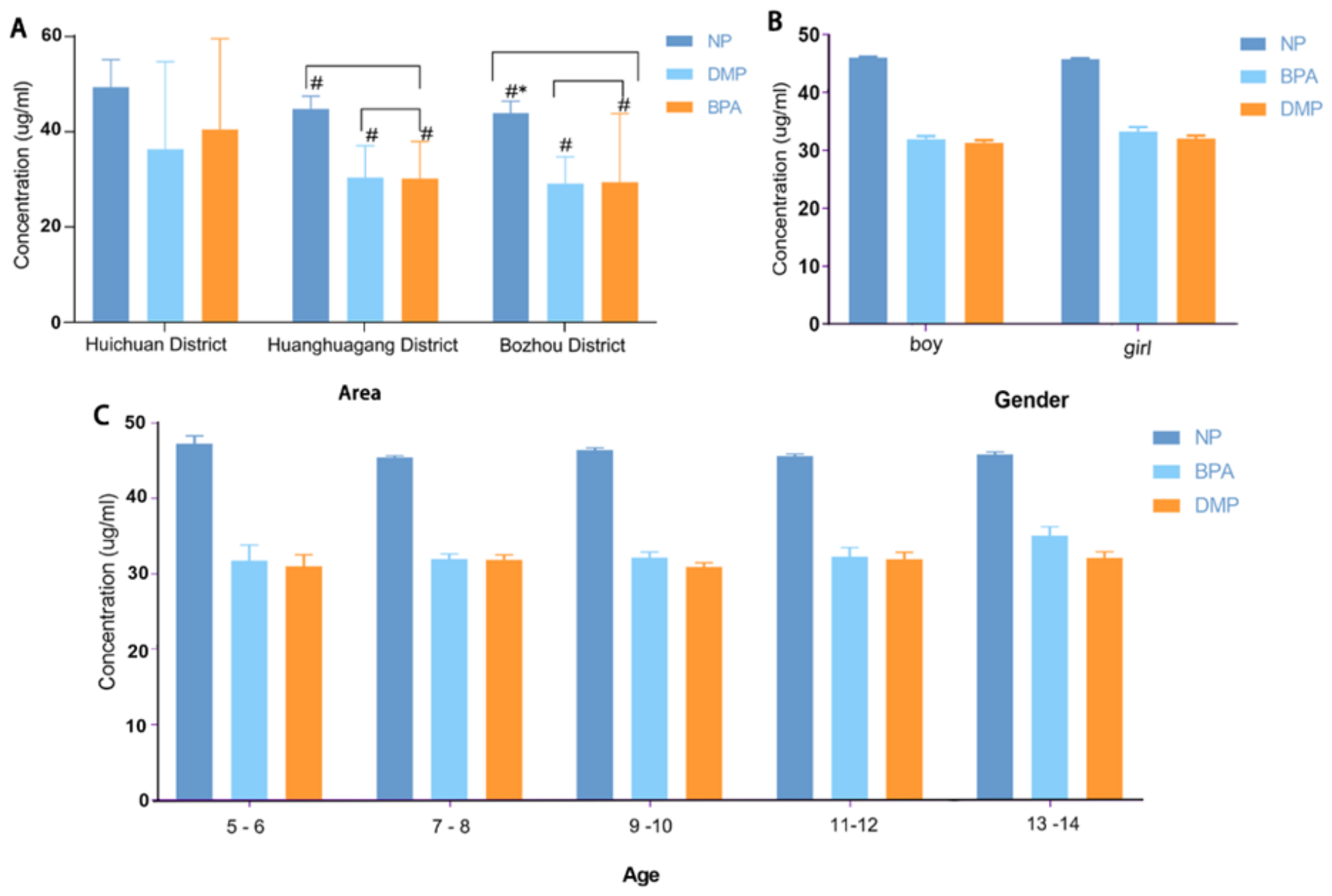

Figure 4

Comparison of the serum concentrations of NP, BPA and DMP of school-age children by address, gender and age. Mann-Whitney U test was used between two groups' comparison, Kruskal-Wallis $\mathrm{H}$ test was used in comparison of multiple groups. \#: vs Huichuan district group, $\mathrm{P}<0.05$; *: vs Honghuagang District group, $\mathrm{P}<0.05$. A. Comparison of the concentrations of NP, BPA and DMP in serum by address, B. Comparison of NP, BPA, DMP in the serum of school-age children by sex, C. Comparison of NP, BPA, DMP in the serum of school-age children by age. 


\begin{tabular}{|c|c|c|c|c|}
\hline \multirow[b]{2}{*}{ Gender } & \multicolumn{2}{|c|}{ Nonylphenol } & \multirow[b]{2}{*}{0.590} & \multirow[b]{2}{*}{$.0 .259(-1.2-0.683)$} \\
\hline & .0 .259 & -1 & & \\
\hline Age & .0 .198 & 블 & 0.343 & $-0.198(-0.609-0.212)$ \\
\hline Decoration times & 0.021 & & 0.967 & $0.021(-0.971-1.012)$ \\
\hline Feeding pattern & .0 .149 & & 0.515 & $-0.149(-0.598-0.3)$ \\
\hline Frequency of perms used during pregnancy & .0 .304 & - & 0.808 & $-0.304(-2.759 \cdot 2.151)$ \\
\hline Frequency of hair gels used during pregnancy & 1.392 & -1 & 0.170 & $1.392(-0.596-3.381)$ \\
\hline Frequency of cosmetics used during pregnancy & 0.728 & 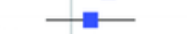 & 0.384 & $0.728(-0.914-2.371)$ \\
\hline Frequency of using plastic lunch box during pregnancy & 0.735 & & 0.086 & $0.735(-0.104-1.573)$ \\
\hline Frequency of plastic water cup used during pregnancy -0 & .0 .553 & - & 0.070 & $-0.553(-1.151-0.045)$ \\
\hline Types of domestic drinking water & 0.231 & & 0.228 & $0.231(-0.145-0.606)$ \\
\hline Frequency of pacifiers used & .0 .247 & & 0.402 & $-0.247(-0.824-0.331)$ \\
\hline Numbers of plastic toys & .0 .002 & & 0.994 & $-0.002(-0.599-0.594)$ \\
\hline Materials for food storage & 0.196 & - & 0.603 & $0.196(-0.546-0.939)$ \\
\hline Frequency of hair dyes used by children & .0 .395 & - 는 & 0.717 & $-0.395(-2.531-1.742)$ \\
\hline Frequency of hair spray and perfume for children & 0.078 & & 0.915 & $0.078(-1.358-1.513)$ \\
\hline Frequency of nail polish and cosmetics used by children $c$ & 0.503 & - & 0.491 & $0.503(-0.932-1.939)$ \\
\hline Frequency of plastic tableware used by children & .0 .747 & $-{ }^{2}-$ & 0.114 & $-0.747(-1.675-0.18)$ \\
\hline Frequency of fish and shellfish intake in children & 0.046 & - & 0.909 & $0.046(-0.743-0.835)$ \\
\hline Update frequency of plastic toys & 0.113 & & 0.735 & $0.113(-0.544-0.771)$ \\
\hline Duration of children birth & .0 .068 & - & 0.874 & $-0.068(-0.915 .0 .778)$ \\
\hline Materials for baby bottle or cup & -0.144 & $\Rightarrow$ & 0.468 & $-0.144(-0.535-0.246)$ \\
\hline Whether exposed to pesticides & .0 .031 & N- & 0.968 & $-0.031(-1.557-1.494)$ \\
\hline Parent occupation classification & .0 .004 & 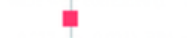 & 0.974 & $-0.004(-0.22-0.213)$ \\
\hline Ways to plastic products & 0.055 & 를 & 0.753 & $0.055(-0.286-0.395)$ \\
\hline
\end{tabular}

\begin{tabular}{|c|c|c|c|c|}
\hline \multirow[b]{2}{*}{ Gender } & \multicolumn{2}{|c|}{ Phthalate } & \multirow[b]{2}{*}{0.038} & \multirow[b]{2}{*}{$2973(0.162 .5 .783)$} \\
\hline & 2.973 & - & & \\
\hline Age & .0 .299 & 둘 & 0.632 & $.0 .299(-1.524 \cdot 0.927)$ \\
\hline Decoration times & -2.255 & $\rightarrow-$ & 0.135 & $-2.255(-5.214 .0 .704)$ \\
\hline Feeding pattern & -1.126 & 들 & 0.100 & $-1.126(-2.467 .0 .215)$ \\
\hline Frequency of perms used during pregnancy & 8.269 & - & 0.027 & $8.269(0.941-15.597)$ \\
\hline Frequency of hair gels used during pregnancy & 1.614 & $\Rightarrow$ & 0.593 & $1.614(-4.322-7.55)$ \\
\hline Frequency of cosmetics used during pregnancy & 3.760 & $\rightarrow-$ & 0.133 & $3.76(-1.144-8.663)$ \\
\hline Frequency of using plastic lunch box during pregnancy & 1.082 & -7 & 0.396 & $1.082(-1.42-3.585)$ \\
\hline Frequency of plastic water cup used during pregnancy & .0 .907 & 블 & 0.319 & $.0 .907(-2.692 \cdot 0.879)$ \\
\hline Types of domestic drinking water & 0.267 & 부 & 0.640 & $0.267(-0.854-1.387)$ \\
\hline Frequency of pacifiers used & 0.251 & $-1+$ & 0.775 & $0.251(-1.473-1.975)$ \\
\hline Numbers of plastic toys & -0.168 & + & 0.853 & $-0.168(-1.948-1.612)$ \\
\hline Materials for food storage & 0.298 & $\rightarrow$ & 0.792 & $0.298(-1.917-2.514)$ \\
\hline Frequency of hair dyes used by children & -3.789 & $\longrightarrow-$ & 0.244 & $-3.789(-10.165-2.587)$ \\
\hline Frequency of hair spray and perfume for children & 3.350 & - & 0.125 & $3.35(-0.934-7.634)$ \\
\hline Frequency of nail polish and cosmetics used by children & -5.319 & - & 0.015 & $-5.319(-9.602-1.035)$ \\
\hline Frequency of plastic tableware used by children & 2.478 & - - & 0.079 & $2.478(-0.291 .5 .247)$ \\
\hline Frequency of fish and shellfish intake in children & 2.186 & - & 0.069 & $2.186(-0.17-0.541)$ \\
\hline Update frequency of plastic toys & .0 .897 & $\rightarrow-$ & 0.370 & $.0 .897(-2.86-1.066)$ \\
\hline Duration of children birth & 1.882 & -1 & 0.144 & $1.882(-0.645-4.41)$ \\
\hline Materials for baby bottle or cup & 0.311 & 帚 & 0.601 & $0.311(-0.855-1.476)$ \\
\hline Whether exposed to pesticides & 2369 & $-1-$ & 0.307 & $2369(-2.185-6.923)$ \\
\hline Parent occupation classification & 0.264 & 口 & 0.424 & $0.264(-0.383-0.911)$ \\
\hline \multirow[t]{2}{*}{ Ways to plastic products } & 0.128 & 미 & 0.804 & $0.128(-0.889-1.145)$ \\
\hline & & 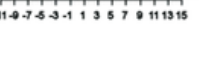 & & \\
\hline
\end{tabular}

\section{Figure 5}

Forest map of correlations between NP, BPA, and DMP and risk factors in multiple linear regression. A: Multiple linear regression relationships between NP and risk factors, B: Multiple linear regression relationships between BPA and risk factors, C: Multiple linear regression relationships between DMP and risk factors. Red color represented basic information. Yellow color represented risk factors of exposure during infancy and exposure in children's current life, Blue color represented risk factors of exposure during mothers pregnancy. Cl: Confidence interval. 

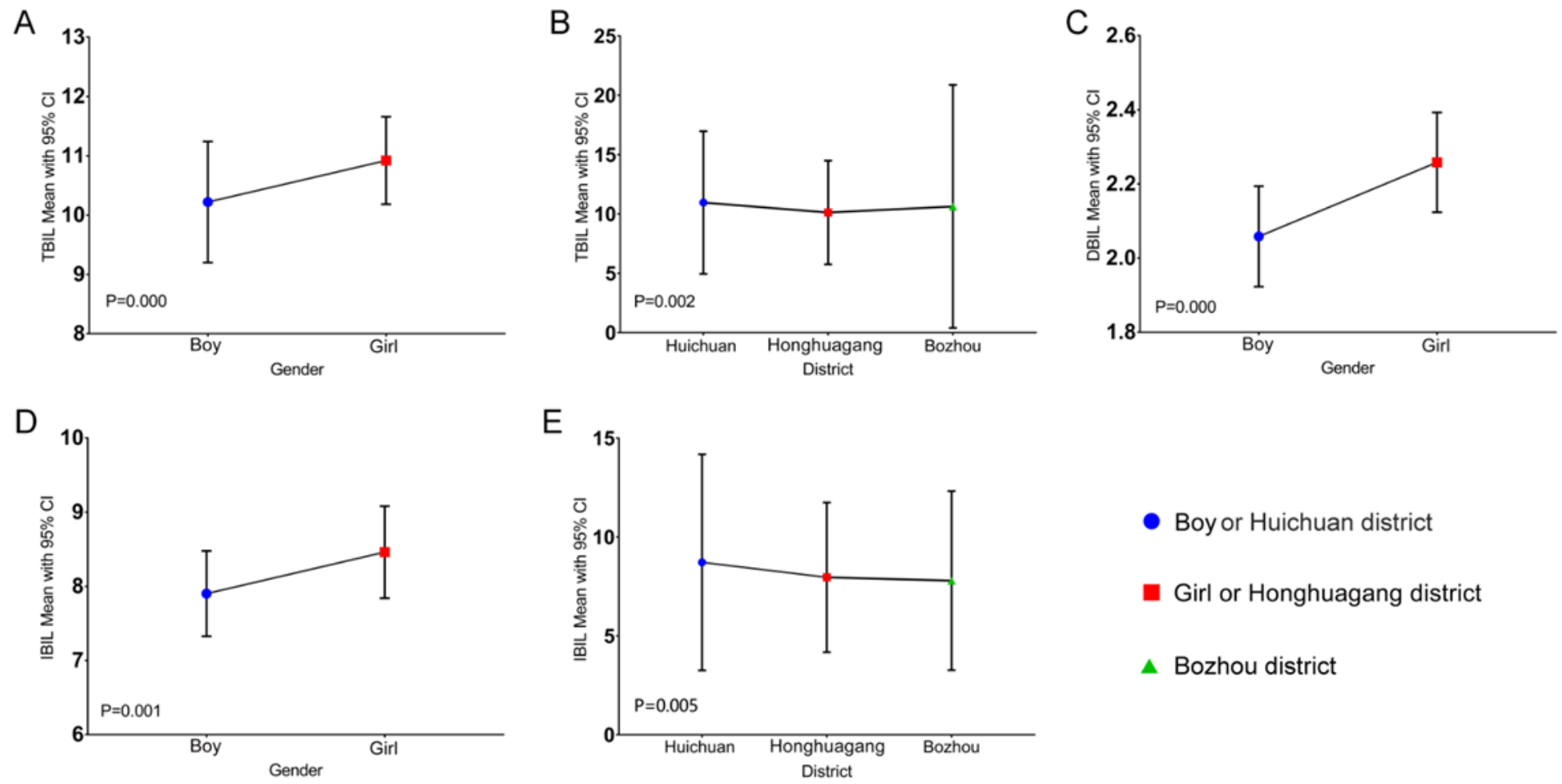

- Boy or Huichuan district

- Girl or Honghuagang district

$\Delta$ Bozhou district

\section{Figure 6}

Comparison of values of TBIL, DBIL and IBIL by address, gender and age. Mann-Whitney $U$ test was used in comparison between two groups, and comparison among multiple groups was analyzed by Kruskal-Wallis $\mathrm{H}$ test. The abscissa was address, gender, and age separately, and the ordinate was the mean with $95 \% \mathrm{Cl}$ of each hepatic function value. If $P<0.05$, it indicated statistical significance, and data without statistical significance was not shown in figures. A: Comparison of the results of TBIL in serum of school-age children by gender; B: Comparison of the results of TBIL in serum of school-age children by address; C: Comparison of the results of DBIL in serum of school-age children by gender; D: Comparison of the results of IBIL in serum of school-age children by gender; $\mathrm{E}$ : Comparison of the results of IBIL in serum of school-age children by address. Abbreviations $₫ \mathrm{OR}$ : odds ratio. Cl: confidence interval. ALT: Alanine aminotransferase. AST: Aspartate aminotransferase. TBIL $₫$ Total bilirubin. DBIL: Direct bilirubin. IBIL: Indirectbilirubin. NP: Nonylphenol. BPA: Bisphenol A. DMP: Dimethyl phthalate. 

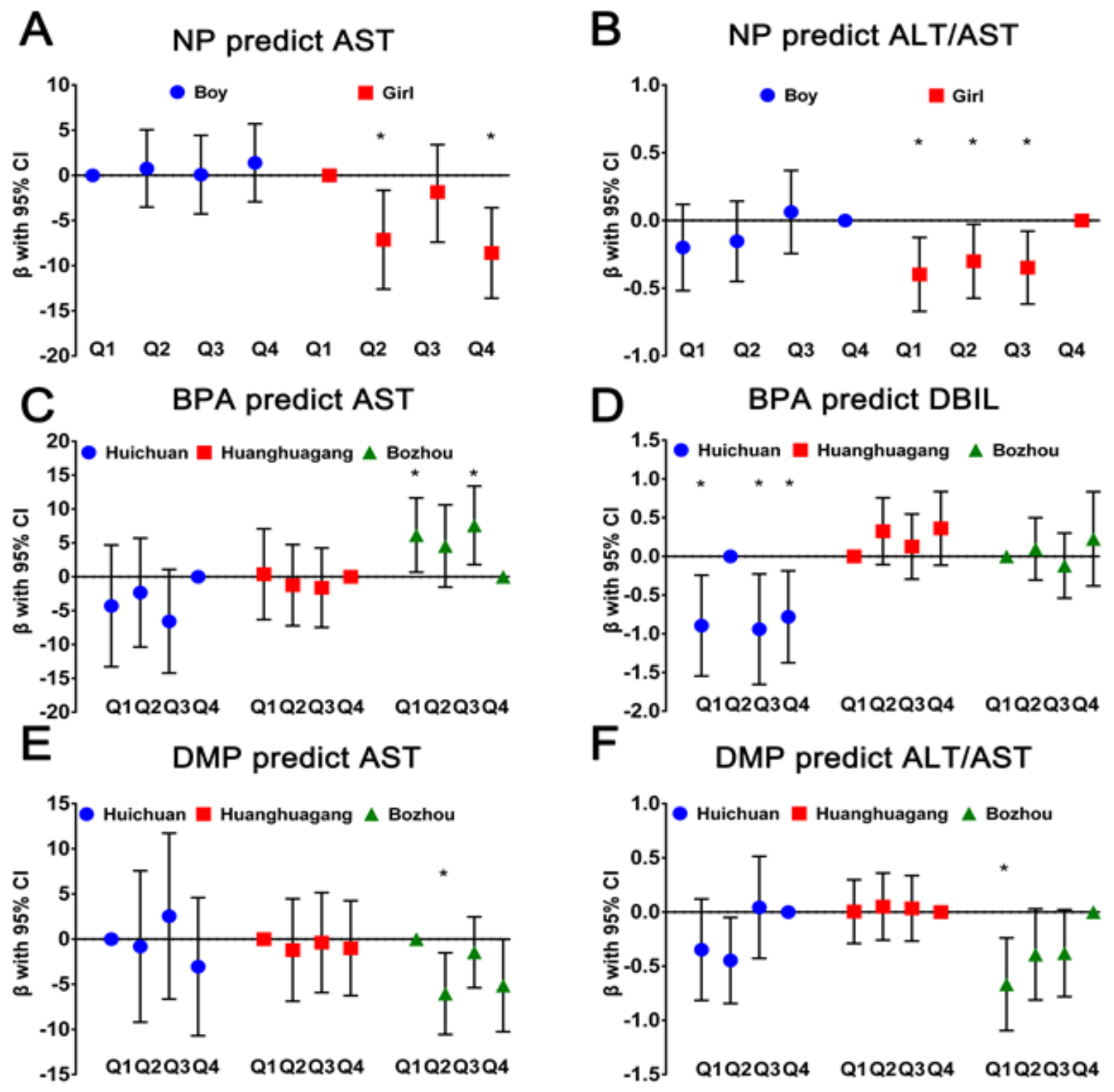

Figure 7

Correlation of 3 EDCs (NP, BPA and DMP) concentrations with hepatic function by gender, age and address. Note: The abscissa was the interquartile range of NP, BPA and DMP concentrations. The ordinate was the $95 \% \mathrm{Cl}$ value of $\beta$ obtained by multiple linear regression with hepatic function indicator as the dependent variable and the concentrations of NP, BPA and DMP as the independent variable. The legend *, which implied statistically significant, was marked if there is no vertical line crossing through the abscissa. A: The relationship between NP and AST by sex. B: The relationship between NP and ALT/AST by sex. C: The relationship between NP and AST by address. D: The relationship between DMP and AST by gender. E: The relationship between DMP and ALT/AST by address. F: The relationship between BPA and DBIL by address. Data with no statistically significant not shown in figures.

\section{Supplementary Files}

This is a list of supplementary files associated with this preprint. Click to download.

- SupplementaryFigure1.doc

- Graphicabstract.tif 
- SupplementaryFigure2.doc

- SupplementaryTable1.doc

- SupplementaryTable2.docx

- SupplementaryTable3.doc

- SupplementaryTable4.docx

- SupplementaryTable5.docx

- SupplementaryTable6.docx

- SupplementaryTable7.docx 